\title{
Ultrastructure of Intervertebral Disc and Vertebra-Disc Junctions Zones as a Link in Etiopathogenesis of Idiopathic Scoliosis
}

\author{
Evalina L. Burger, ${ }^{1}$ Andriy Noshchenko, ${ }^{1}$ Vikas V. Patel, ${ }^{1}$ \\ Emily M. Lindley, ${ }^{1}$ and Andrew P. Bradford ${ }^{2}$ \\ ${ }^{1}$ The Spine Center, Department of Orthopaedics, University of Colorado Denver, Aurora, CO 80045, USA \\ ${ }^{2}$ Division of Basic Reproductive Sciences, Department of Obstetrics \& Gynecology, University of Colorado Denver, \\ Aurora, CO 80045, USA \\ Correspondence should be addressed to Andriy Noshchenko; andriy.noshchenko@ucdenver.edu
}

Received 24 September 2013; Accepted 1 February 2014; Published 23 March 2014

Academic Editor: Chan S. Shim

Copyright ( 2014 Evalina L. Burger et al. This is an open access article distributed under the Creative Commons Attribution License, which permits unrestricted use, distribution, and reproduction in any medium, provided the original work is properly cited.

\begin{abstract}
Background Context. There is no general accepted theory on the etiology of idiopathic scoliosis (IS). An important role of the vertebrae endplate physes (VEPh) and intervertebral discs (IVD) in spinal curve progression is acknowledged, but ultrastructural mechanisms are not well understood. Purpose. To analyze the current literature on ultrastructural characteristics of VEPh and IVD in the context of IS etiology. Study Design/Setting. A literature review. Results. There is strong evidence for multifactorial etiology of IS. Early wedging of vertebra bodies is likely due to laterally directed appositional bone growth at the concave side, caused by a combination of increased cell proliferation at the vertebrae endplate and altered mechanical properties of the outer annulus fibrosus of the adjacent IVD. Genetic defects in bending proteins necessary for IVD lamellar organization underlie altered mechanical properties. Asymmetrical ligaments, muscular stretch, and spine instability may also play roles in curve formation. Conclusions. Development of a reliable, cost effective method for identifying patients at high risk for curve progression is needed and could lead to a paradigm shift in treatment options. Unnecessary anxiety, bracing, and radiation could potentially be minimized and high risk patient could receive surgery earlier, rendering better outcomes with fewer fused segments needed to mitigate curve progression.
\end{abstract}

\section{Introduction}

There is no generally accepted scientific theory for the etiology of idiopathic scoliosis (IS). Treatment of this disease remains pragmatic with an incomplete scientific basis [1]. The current strategy of treatment depends on a patient's age [2]. In children, scoliotic deformity causes a persistent stress in the motion segments, which induces a progressive elastoplastic strain that modifies the geometry of the motion segment, which in turn worsens the excessive strain $[2,3]$. Thus, in the pediatric spine the aim of treatment is to prevent the motion segment deformity. In adult scoliosis, significant deformation of the intervertebral disc (IVD) and the capsuloligamentous structures produce instability of the motion segments and slow deformation of the vertebrae through remodeling with disc herniation and neural compression. Hence in adult scoliosis a stable balance is necessary to prevent further deformation of the spine [3-5].

IS may be observed in the infantile, juvenile, or adolescent period, but the trigger factor for curve onset is unknown. There is evidence that the spinal growth spurt plays a significant role in the onset and progression of spinal deformation, especially in the adolescent period. It has been shown that spinal growth can be attributed to increases in the vertebrae height, while the height of discs does not increase $[1,6]$. This is likely modulated by loading, according to the Hueter-Volkmann principle [2, 7]. Human vertebrae grow longitudinally by ossification of the vertebral endplate physes 
(VEPh). VEPh adjacent to the discs produce longitudinal growth, while appositional growth enlarges the vertebrae in diameter $[1,8]$. Theoretically, axial compression can diminish axial growth by reducing the number of proliferating chondrocytes in the hypertrophic zone [9]. Wedging of discs in scoliosis may be caused by asymmetric tissue remodeling or selective concave side degeneration [10]. As scoliosis tends to progress during the growth spurt, it is possible that the growth plate plays an important role in the development of the deformity [9-11]. The interaction between VEPh and adjoined IVD could play a significant role in the initiation and progression of the spinal deformation, especially at the apical zone. Stokes and Aronsson [12] noted that while the IVD does not appear to be the primary factor in the etiology of IS, the IVD contributes to the progression of the scoliosis curve when it becomes significantly wedged. The IVD interface under load shows characteristics of dysplasia which can be associated with changes in discal properties [1]. Despite many studies on the etiology and pathogenesis of scoliosis, the interaction between VEPh and IVD both morphologically and ultrastructurally has not been studied well.

The purpose of the present paper is to review current literature on the morphological and ultrastructural characteristics of the IVD and the VEPh in relation to the clinical manifestation of IS, with an emphasis on the etiology and pathogenesis of this disease. We below present a review of: (a) clinical manifestation of IS; (b) etiological and pathogenetic factors and concepts of IS; (c) morphological and ultrastructural features of the IVD and VEPh in IS. The following sources of information were used to collect the data: (1) electronic data bases: Ovid Medline and Embase till September 2013; (2) hand search using reference lists of reviews and book chapters; no restrictions concerning type of publication and language were used.

\section{Clinical Manifestation of IS}

IS was originally defined as a structural, lateral curvature of the spine of unknown etiology [13]. The Scoliosis Research Society then defined scoliosis as a lateral curvature of the spine which exceeds 10 degrees by the Cobb method on a standing radiograph [14]. Later it was noted that the presence of structural rotation at the apical segment is essential [15]. Currently, scoliosis is regarded as a three-dimensional curvature of the spine in the coronal and sagittal planes with rotation in the axial plane [12]. If the curvature is present before skeletal maturity and has no other diagnostic features that categorize it as neuromuscular, congenital, traumatic, infectious, postinfectious, or syndrome-related, then it is regarded as IS [15]. The age of onset is the basis of the classification. Infantile IS (IIS) idiopathic scoliosis (IIS) starts before age $3(\approx 1 \%$ of cases), juvenile (JIS) occurs between 3 and 10 years (around $20 \%$ of cases), while adolescent IS (AIS) is defined, if curve onset is between 10 years and skeletal maturity [16]. There are also distinctions in the clinical appearance between different forms of IS. IIS often has spontaneous resolutions (20\% and $80 \%)$, predominant in boys, and mostly has left thoracic curvature. The curve is seldom present at birth and mainly develops during the first 6 month of life. Resolved curves typically do not recur during the adolescent growth spurt. In adulthood very few patients have back pain or an increased disability score $[13,17,18]$. Thoracic and lumbar curves that reach between 50 and 80 degrees at skeletal maturity may continue to progress slowly in adult life [19]. IIS is also associated with plagiocephaly ( $100 \%$ of children with early onset of IIS), mental retardation, congenital heart disease, and congenital dislocation of the hip [20]. Congenital inguinal hernia and generalized joint laxity have been found among relatives of diseased children [20]. Using magnetic resonance imaging (MRI) demonstrated that the incidence of neural axis abnormalities in children with IIS and JIS is around 20\% including Arnold-Chiari malformation, associated cervicothoracic syringx, syringomyelia, and low-lying conus [21, 22]. Wynne Davies [20] suggested that the etiology of IIS must be multifactorial, with a genetic tendency to the deformity which can then be "triggered off" in different individuals by different factors, some medical, some themselves genetic, and some social. JIS is prevalent in boys between ages four and six and in girls between ages seven and nine $[13,23,24]$. Right sided curves are observed in $50-77.5 \%$ of cases, regardless of sex or age. A single thoracic curve is the most common (around 62\%), followed by double thoracic and lumbar (22\%) and thoracolumbar (15\%). Curve progression is difficult to predict. Spontaneous resolutions are much less common than in IIS (around $7 \%$ ) [23], and progression may occur in more than $50 \%$ of cases [24]. Associated diseases were observed in $29 \%$ of patients including mental deficiency (12\%), spina bifida occulta $(6 \%)$, inguinal hernia $(3 \%)$, epilepsy $(2 \%)$, pyloric stenosis (2\%), congenital dislocation of hip (1\%), dextrocardia (1\%), metatarsus varus (1\%), joint laxity (1\%), hemimelia (1\%), and absent thumb (1\%) [23]. Around 13\% of all patients with JIS have a history of family involvement [23]. Patients with JIS are at risk of curve progression during pubertal growth, especially if the curve exceeds $30^{\circ}$ at the onset of the pubertal growth spurt [25]. AIS occurs in $2-4 \%$ of children during the pubertal growth spurt, mainly in females [14, 26, 27]. The ratio of girls to boys increases from 1.6:1 at 9-10 years of age to $6.4: 1$ at 11-12 years of age [28]. Thoracic curves are observed in 33\%-48\% [28-30], thoracolumbar/lumbar $21 \%-40 \%$ [28-30], double/triple curves 9\%-38\% [28-30], and lumbar curves around $8 \%[28,29]$. Data concerning rate of curve progression are heterogeneous and vary from $1.6 \%$ to $68 \%$ depending on the study and subjects enrolled [31]. Soucacos et al. [32] reported by results of 6-year prospective cohort study in Greek population that curve progression occurs in around $15 \%$ of children with AIS, while $27.4 \%$ demonstrate spontaneous improvement of at least 5 degrees. $\mathrm{Xu}$ et al. [30] suggested that in skeletally immature AIS patients (Risser sign 0-3) with initial curve magnitude ranging from 20 to 40 degrees rate of curve progression was $24 \%-32 \%$ depending on the type of spine deformity. Risk factors for curve progression include type of spine deformity, in particular, right thoracic and double curves in girls, and right lumbar curves in boys; age at onset of menses in girls (although data are contradictive); menarche status; skeletal maturity (Risser sign 0-3); and 
curve magnitude equal to or greater than $30^{\circ}[32,33]$. An MRI study of the brainstem and spinal cord showed that $2 \%$ of children with presumed AIS had such abnormalities as hydrosyringomyelia, Arnold-Chiari malformation tethered spinal cord, tumor, and diastematomyelia [34]. This is approximately ten times less than in patients with infantile and juvenile IS. An epidemiological case-control study revealed evidence of a genetic component in the etiology of AIS [35].

The data above imply that genetic predisposition plays a significant role in the etiology of IS; however genetic determinants of the disease are likely multifactorial. These variations may determine clinical features such as age of clinical manifestation, gender, association with congenital malformations, type of scoliotic curve, severity of curve progression, or resolution.

\section{Etiological and Pathogenetic Factors and Concepts of IS}

Current etiologic research on IS focuses on biological and biomechanical factors and relates mainly to the growth of the central nervous system (CNS), disturbances of bilateral symmetry and development instability, hormonal regulation and intercellular signaling, platelet calmodulin, melatonin, muscles, bone density, elastic fibers, and the skeletal framework including vertebral disproportionate growth and genetics [11]. There are several hypotheses pointing to congenital disorders of the CNS as an important factor in scoliotic spine deformation. The following sections describe the primary hypotheses.

3.1. The Nottingham Concept. This concept was proposed by Burwell and coauthors in 1992 and focuses on the relationship between developmental abnormality in the CNS and ribvertebra angle asymmetry, which leads to a cyclical failure of the mechanisms of rotational trunk control involving falls. This in turns leads to the initiation of the deformity with loss of lordosis. Curve progression occurs as a result of gravity acting on both the abnormal as well as the normal vertebral growth [36].

\subsection{Neurodevelopmental Concept of Maturational Delay of the} CNS Body Schema. This concept was proposed in 2006 [37] as a further development of the Nottingham concept and suggests that spine deformity in scoliosis is the result of a combination of different factors including left-right skeletal length asymmetries involving growth plates (physes) and probably vertebral body growth plates; periapical rib length asymmetry; neuromuscular asymmetry; the rapid spinal elongation in the adolescent growth spurt that results from growth principally of vertebral body growth plates under the influence of steroid hormones; a delay in CNS maturation leading to impaired neuromuscular adjustments on a rapidly elongating spine; and movement of the spine and trunk in the upright posture unique to humans which leads to the neuromuscular adjustment of the rapidly elongating spine.
The results of the experimental and clinical studies all confirm the association of the CNS disorders with scoliosis development [38-46]. Unfortunately it is difficult to conclude whether the CNS dysfunctions reflect a possible cause of scoliotic spine deformity, consequence, or whether they develop parallel to the curve formation.

According to the Neurodevelopmental concept, which regards dysfunction of the CNS as a primary factor of IS, changes in the vertebrae-disc interaction must be secondary and may be caused by the axial load asymmetry.

\subsection{The Braking of Bilateral Symmetry in relation to Left-Right} Asymmetry Initiated in Embryonic Life. It has been suggested that developmental instability may be the initial factor in scoliotic curve formations having genetic determinants [4749]. This conclusion was based on the fact that children with AIS have increased left-right asymmetry including arm and leg length, trunk shape, breast size, skull and face, teeth, brain stem, femoral neck-shaft angles, dermatoglyphic characteristics, vibration sensitivity, and somatosensory perception $[44,47,50-56]$.

If the concepts of braking of bilateral symmetry and developmental instability are true, we can expect existence of a primordial morphological asymmetry in the structure of the vertebrae endplates, annulus fibrosus of the discs, and the disc-vertebrae joints not only at the apical level, but also at other spine levels.

3.4. The Neuroendocrine Hypothesis. Initially this hypothesis suggested melatonin deficiency as a source for AIS, and stems from the fact that pinealectomized chickens and pinealectomized rats maintained in a bipedal mode developed spine deformities more often than controls [5759]. The same result was obtained in melatonin-deficient mice without pinealectomy [60]. The spine deformity development in pinealectomized chickens correlated with delay of the cortical somatosensory evoked potentials, suggesting a conduction disturbance of brain stem function. It was suggested that these findings implicate neurotransmitters or neurohormonal systems in the pineal body as a major contributing factor in this type of experimental scoliosis [57]. Machida et al. [61] reported that the level of serum melatonin was significantly lower in patients who had progressive curves in comparison with those who had a stable curve. The level of melatonin appeared to be a useful predictor for progression of spine curvature in IS, but further experiments in nonhuman primates and other clinical trials have not confirmed this conclusion [62-67].

3.5. Impairment of Melatonin Signaling Transduction. Moreau et al. [68] have shown that melatonin signaling was impaired in cultured osteoblasts from AIS patients to different degrees allowing their classification in 3 distinct groups. The authors suggested the presence of distinct mutations, interfering with melatonin signal transduction. Their conclusion was that changes in G-proteins functioning which are an important link in the intracellular melatonin signaling can be considered a possible mechanism in the etiopathogenesis 
of AIS. A hypofunctionality of G-proteins may be caused by increased serine phosphorylation leading to their inactivation, which is provided by kinases and phosphatases. Protein kinase C delta (PKC $\delta$ ) is one of them. Azeddine et al. [69] demonstrated the ability of PKC $\delta$ to compose a complex with melatonin receptors MT2 in osteoblast cells derived from AIS patients. Such complexes were not detected in control cells. Further studies have shown an asymmetric expression of melatonin receptor mRNA in bilateral paravertebral muscles in patients with AIS [70]. It has been also found that a polymorphism of the promoter of the melatonin receptor $1 B$ (MTNR1B/MT2) gene is associated with AIS [71]. Such an association was not found for the melatonin receptor $1 \mathrm{~A}$ (MT1) gene [72]. There is also evidence that the function of G-protein-coupled receptors may be modulated by estrogen. In particular, 17 beta estradiol may activate MT1 receptors, increase MT2 receptors density [73], and correct or diminish melatonin signaling dysfunction revealed in osteoblasts taken from patients with AIS [74].

Melatonin signaling affects cell processes on several levels by binding to two specific G-protein coupled receptors, MT1 and MT2. One or both of these receptors exist on a variety of cell types. Melatonin receptors are associated primarily with four G-protein subunits. Melatonin signaling is generally a negative regulator of cell function via reduction of intracellular messengers such as cAMP, $\mathrm{Ca}^{2+}$, and cGMP (cyclic guanosine monophosphate) via G-protein subunits. Melatonin also regulates cell processes via nuclear signaling and transcription factors [75]. Melatonin may increase cAMP accumulation in the osteoblasts of patients with IS [68]. To note, cAMP is used for intracellular signaling transduction and is involved in the regulation of different cell functions, including synthesis and proliferative activity. There are some data that cAMP and G-proteins participate in the effects of mechanotransduction in different tissues, including bone and cartilage [76-79]. Changes in the melatonin transduction pathways may significantly modify cellular activity including osteoblasts and osteoclasts. Melatonin is an important regulator of bone modeling and remodeling and is synthesized by the pineal gland and bone marrow [80]. Data on the direct effect of melatonin on bone cells are contradictory. It was reported that melatonin promotes osteoblast cell differentiation and proliferation [81] and increases bone mass by suppression resorption through downregulation of osteoclast formation and activation [82]. However, other authors report on the suppressive effect of melatonin on osteoblastic and osteoclastic activities [83]. It was noted that an inhibitory effect of melatonin on osteoblastic cells was seen when incubated in the presence of osteoclastic cells [84]. If the inhibitory effect of melatonin on both the cell lines is true, we may suppose that a defect in melatonin transduction in combination with other factors contributes to the accelerated anterior vertebral endochondral bone overgrowth, which in turn correlates with scoliotic curve occurrence and more active longitudinal growth of patients with AIS in comparison with their peers [85-87]. Increased osteoclast activity may cause stimulation of bone remodeling leading to spine slenderness. It may also explain the fact that in patients with AIS the longitudinal growth of the spinal cord fails to keep up with the pace of the growth of the vertebral column (disproportionate neuroosseous growth) [88].

Based on these results it is possible to speculate on the features that we may find in the morphological structure of vertebrae endplates, intervertebral discs, and their junctions in patients with IS. In particular, we may expect to find increased proliferative activity different from the age related changes and effects of the axial load asymmetry.

3.6. Platelet Calmodulin as Predictor of Scoliotic Curve Severity. The role of platelets in the pathogenesis of IS has been discussed for many years. It was noted that platelets and muscle fibers share the same contractile proteins (actin and myosin). In scoliotic patients, both spinal and peripheral muscles showed frequent abnormalities when examined by light and electron microscopy $[89,90]$. Patients with IS differed from patients with other types of scoliosis [89]. They had increased calcium content and decreased muscle spindles in their muscles. It was suggested that there is a specific neuromuscular disorder causing IS linked with a membrane defect-namely impaired calcium pump [91]. Structural and functional abnormalities of platelets attributed to a defect of calcium transport in the membrane and/or contractile protein metabolism were also reported in patients with AIS [90]. Later Kindsfater et al. [92] and Lowe et al. [93] showed that platelet calmodulin levels correlate with scoliotic curve progression. They even proposed to use this index as a predictor of the curve progression. The significant difficulty in this field was the lack of normal data and the large variability in baseline levels for platelet calmodulin [94]. It was suggested that changes in the platelet calmodulin are acquired and parallel to curve progression reflecting systemic defects of cell membranes [92].

3.7. Platelet/Skeletal Hypothesis. Burwell and Dangerfield [95] proposed the platelet/skeletal hypothesis, which involves morphological, mechanical, vascular, platelet, hormonal, and growth mechanisms. This hypothesis assumes that presence of a small scoliosis curve in the human upright position alters the vertebral body growth endplate physes, which lead to microinsults. These microinsults activate endothelial cells, which then results in dilated vessels and vascular "lakes" adjacent to the disc growth plates. Activated platelets circulate through vessels, particularly in the curve apex on the medullary aspect of endplate physes. The platelets are activated by the slowing of blood flow in the dilated vessels and vascular "lakes", repeated mechanical microinsults that lead to vascular damage with exposure of endothelial collagen, endothelial cells, and release of different intracellular signaling factors. Platelet activation is associated with a calcium-calmodulin complex formation. Vertebrae growth plates are stimulated by growth factors from platelets as well as mechanically. It promotes an overgrowth and a spine deformity progression. A molecular predisposition to platelet activation may involve hormones and genetic polymorphisms. 
We would like to point out another possible mechanism, which may explain the increase of platelet calmodulin levels in some patients with IS. As described above, a defect in melatonin signaling transduction associated with the impaired of G-protein cAMP inhibition was revealed in the osteoblasts of patients with IS [68]. This finding is consistent with the polymorphism of the promoter of melatonin receptor $1 \mathrm{~B}$ gene, which was later reported [71]. It should be noted that human platelets use the same melatonin signaling mechanisms as in the osteoblasts, including melatonin receptors and G-protein-cAMP inhibition system [96]. Besides, melatonin inhibits several physiological intracellular processes [97], including the activity of $\mathrm{Ca}^{2+} /$ calmodulin-dependent protein kinase II (CaM-kinase II), and acts as a universal calmodulin antagonist in cells inhibiting $\mathrm{Ca}^{2+}$ influx [98]. If melatonin signaling is impaired in platelets, then platelet activation may be associated with an increase in cAMP generation, increase in the calmodulin and $\mathrm{Ca}^{2+}$ levels, and inhibition of aggregation. Inhibition of platelet aggregation is used as a marker of decreased G-protein activity and increased cAMP generation [99]. Thus, if impaired melatonin signaling is involved in IS, than platelet aggregation must be decreased in patients with IS. Unfortunately, the results of clinical studies are contradictory. Se Il Suk et al. [100] tested bleeding time, platelet aggregation, and titer of platelet plasminogen activator inhibitors in 52 patients with IS and in 49 controls. Statistically significant differences were not found. However, a more recent study performed by Ho et al. [101] showed that among 32 patients with IS who underwent preoperative coagulation screening tests, 8 had prolonged activated partial thromboplastin time and 5 were diagnosed with a specific coagulation abnormality potentially associated with increased bleeding. It was concluded that in the tested group of patients with IS, the risk of specific inherited haemostatic disorders was higher (around 10 times) than in the general population. Theoretically, an increase in platelet calmodulin levels and other changes in platelet functions and morphology observed in IS may be a cell specific secondary effect of such systemic disorder as melatonin signaling defect, which is genetically predisposed and linked with melatonin receptors and G-protein dysfunction. It is known that Gprotein signaling defects in platelets are mainly subclinical [102]. Also, it has been known for years that certain cellular functions of platelets and in neurosecretory cells are very similar $[102,103]$. Thus, some neurological dysfunctions in IS may also be explained by the melatonin signaling defect.

3.8. The Elastic Fiber System Role in the Pathogenesis of Idiopathic Scoliosis. Hadley-Miller et al. [104] studied the elastic fiber system using fresh-frozen histological specimens of ligamentum flavum removed from 23 patients with scoliosis and 5 age-matched controls at the time of an operation. Abnormalities on immunohistochemical staining including a marker for disarrangement of the fibers and differences in density of staining were found in 18 of the scoliotic specimens. It was also noted that in 4 scoliotic cases the amount of secreted fibrillin was normal, but the fibrillin failed to bind to other macromolecules, to form a sedimentable complex and to incorporate into the extracellular matrix. It was assumed that mutations in the gene encoding for fibrillin caused the production of abnormal fibrillin, such as in Marfan's syndrome. Research in this field is very important not only because ligaments play a significant role in spine stability, but also because fibrillins take part in embryonic development, in particular, skeletal elements, and skeletal muscle $[105,106]$. In addition, some cells in the annulus fibrosus of IVD have been described as fibroblast-like [107]. There is evidence that melatonin may significantly modify the activity of fibroblasts. For instance, strong expression of basic fibroblast growth factor (bFGF) was found in the epineurium of rats that underwent pinealectomy in comparison with control and melatonin treated animals [108]. The role of these mechanisms in the etiopathogenesis of IS has not yet been investigated.

3.9. Changes of the Hormonal Regulation. Clinical observations have revealed a tendency for increased thoracolumbar spine height and slenderness in children with IS [86-88, 109]. Skogland and Miller [110] showed that girls with IS had a significantly higher response to the growth hormone stimulation test than controls. Higher growth hormone secretion was also found by Ahl et al. [111] among girls with IS in the pubertal stage. Interestingly, the level of serum somatomedin A (insulin-like growth factor-2) in girls with IS was lower than in controls [112]. Some authors report an increased risk of scoliosis progression in patients treated with growth hormone $[113,114]$, while another did not confirm this finding [115]. Growth hormone (somatotropin) is synthesized and secreted by the anterior pituitary gland. It stimulates growth and cell reproduction and stimulates cellular division in cartilage by acting through both systemic and local insulin-like growth factors (IGF) [116]. Several genetic studies have not shown a significant association between AIS and the singlenucleotide polymorphism of the growth hormone receptor and IGF-1 gene $[117,118]$. However, an association between IGF-1 polymorphism and type of AIS spine deformity was found in Korean population [119]. Serum concentration of IGF1 significantly correlates with curve acceleration [120]. It should be noted that melatonin modulates secretion of growth hormone and IGF in culture, inhibits pituitary cAMP accumulation, and reduces growth hormone release [121]. Significant modulation of function of growth hormone function by melatonin was shown in rats [122]. In particular, melatonin inhibits endogenous production of IGF1 [123]. Thus, a defect in melatonin signaling may provoke secondary changes in the function of growth hormone-IGF1 axis and cause bone growth stimulation effects.

Published data concerning serum content of testosterone in AIS are contradictive. Skogland and Miller [110] revealed significantly increased mean serum levels of testosterone in girls with AIS, whose skeletal age was between 9 and 12 years. Raczkowski [124] also reported on the relative increased level of testosterone in girls aged 12-17 years with moderate and severe right thoracic curves (AIS) in comparison with girls of the same age with mild left lumbar scoliosis, while Esposito et al. [125] revealed decrease serum testosterone in 
AIS, but types of spine deformity were not taken into consideration. Theoretically, increased levels of testosterone may contribute to vertebrae overgrowth and scoliosis progression. Androgens stimulate trabecular and cortical bone modeling independently from systemic or local IFG1 production in males [126]. Testosterone metabolism in the growth zone chondrocytes of females has some differences causing specificity of the response [127]. Interestingly, nocturnal melatonin secretion is increased in patients with hypogonadotropic hypogonadism and testosterone administration normalizes melatonin concentrations in these patients [128]. Thus, it is possible to assume that an increased level of testosterone in girls with AIS may be associated with a defect in melatonin signaling.

Estrogen levels in AIS also appear to be important, but the data are conflicting. Skogland and Miller [110] did not find significant differences in blood levels of estradiol, prolactin, follicle stimulating hormone, or luteinizing hormone between girls with AIS and controls, aged 7-17 years. Raczkowski [124] also reported on the absence of statistically significant differences in estrogen levels during the follicular and luteal phase between girls, aged 12-17 years, with right thoracic scoliosis and slight lumbar functional scoliosis. However, Kulis et al. [129, 130] have found a significantly lower level of estradiol and parathormone in girls with IS aged 11-14 in comparison with healthy controls. Esposito et al. [125] also reported on lower blood content of $17 \beta$-estradiol and progesterone in AIS girls with respect to control. Decreased level of estradiol observed at the earlier pubertal period may reflect a maturity delay. On the contrary, Goldberg et al. [131] reported that menarche in girls with IS in the Irish population was 0.39 years earlier than the national mean. Those diagnosed at a younger age were generally taller than their peers, indicating that the growth spurt in girls with IS was earlier. A study in Scandinavian girls found that menarche occurs significantly later in girls with a thoracolumbar or a double primary curve than in the control group. At the time of menarche, the girls with a thoracolumbar or double primary curve were significantly taller than those in the control group [132].

A decreased estrogen level corresponds with a decrease in bone mineral content (BMC), bone mineral density (BMD), lower osteocyte count, and lower trabecular thickness in the trabecular bone in girls with IS [133, 134]. Estrogen deficiency leads to an increase in bone remodeling in which resorption overtakes formation through an increase in immune function, which culminates in an increased production of tumor necrosis factor (TNF) by activated $\mathrm{T}$ cells. TNF increases osteoclast formation and bone resorption both directly and by augmenting the sensitivity of maturing osteoclasts to the essential osteoclastogenic factor RANKL [135]. The mechanism by which estrogen plays a role in IS may be linked with calmodulin. There is evidence that calmodulin decreases the estrogen binding capacity of estrogen receptors [136]. It is possible that increased intracellular levels of calmodulin that result from impaired melatonin signaling may contribute to decreased effects of estrogen while the estrogen level in blood is normal in patients with IS. Decreases in parathormone in patients with
IS [130] require further research and explanation. Current experimental data suggest that vitamin D3 and melatonin modulate the secretory activity of parathyroid gland [137139].

It has been found that blood leptin levels are significantly decreased in girls with AIS [140, 141]. It was suggested that leptin plays an important role in the lower body mass, growth parameters, and bone mineral density in AIS girls. Causes of the reduced levels of circulating leptin in AIS have not been studied yet. Leptin is an adipose derived hormone that plays a key role in regulating energy intake and expenditure. It was shown in experiments that leptin may stimulate osteoblastic differentiation in vitro, likely promoting the expression of osteoblastic related genes [142]. Leptin can also act through hypothalamus augmenting signals that enhance osteocalcin excretion from osteoblasts that modulate glucose-insulin and weight homeostasis [143]. On the other hand, leptin is able to stimulate sympathetic neurons in the hypothalamus and indirectly inhibit bone formation. This effect may be diminished by administration of beta-adrenoblockers [144]. To note, melatonin interacting with insulin upregulates leptin expression by adipose cells [145]. Thus, it is possible to assume that a decreased level of circulating leptin may be associated with an impairment of melatonin signaling in adipocytes. Burwell et al. [146] proposed a "double neuroosseous theory" of pathogenesis of AIS in girls, which postulates that developmental disharmony expressed in spine and trunk between autonomic and somatic nervous systems leads to AIS. The important component of this theory is increased sensitivity of the hypothalamus to circulating leptin with bilateral asymmetry of the sympathetic nervous system response, which causes an asymmetry in axial skeletal growth and initiates the scoliotic spine deformity. A growth hormone-IGF axis plays a role as a modulator of these processes. The developmental abnormalities are accompanied by osteopenia, intervertebral disc degeneration, and platelet calmodulin dysfunction. However, the author noted that this double neuroosseous theory requires testing [146].

Thus, some features of hormonal regulation observed in patients with IS may be initiated by different predominant factors, the changes in hormonal regulation play a significant role in the morphological structure of bones, vertebrae endplates, and intervertebral discs contributing to a faster growth spurt, increased bone remodeling, decreased bone mineral density, and spine slenderness. Therefore, corresponding attributes may be observed in the vertebrae endplates and IVD structure at the different levels of the scoliotic spine.

3.10. Genetic Factors. Study of AIS in twins demonstrated that monozygous twins have a significantly higher rate of concordance and correlation between curve development and progression than dizygous twins $[35,147]$, suggesting a genetic predisposition to the disease [148]. Potential candidate genes have been previously identified [149-151]. Single nucleotide polymorphisms (SNPs) of different genes have been defined as having association with susceptibility or progression of AIS during last decade, Table 1. These include 
TABLE 1: Genes showed an association with AIS.

\begin{tabular}{|c|c|c|c|}
\hline \# & Identified Genes & Population tested & Published by \\
\hline 1 & $\begin{array}{l}\text { Genes potentially associated with IS: } \\
\text { 2p15-13, 6q13, 15q12 }\end{array}$ & Analysis of the Human Cytogenetics Database & Brewer et al., 1998 [149] \\
\hline 2 & $\begin{array}{l}\text { Genes associated with IS: } \\
6 \mathrm{p} \text {, distal } 10 \mathrm{q}, 18 \mathrm{q}\end{array}$ & $\begin{array}{l}\text { A genome-wide search in one large family ( } 7 \\
\text { affected members). }\end{array}$ & Wise et al., 2000 [151] \\
\hline 3 & $\begin{array}{l}\text { Genes associated with IS: } \\
\text { 19p13.3 (D19S216; D19S894; D19S1034) } \\
\text { D2S160-D2S347-D2S112 } \\
\text { No linkage was found with markers on the X } \\
\text { chromosome }\end{array}$ & $\begin{array}{l}\text { Seven families with AIS consisting of } 25 \\
\text { affected members were studied. }\end{array}$ & Chan et al., 2002 [165] \\
\hline 4 & $\begin{array}{l}\text { Genes associated with IS: } \\
\text { Xq23 (GATA172D05) in 15\% of studied families } \\
\text { stratified for genetic heterogeneity }\end{array}$ & $\begin{array}{l}202 \text { families with at least } 2 \text { individuals with IS } \\
\text { (total of } 1198 \text { individuals were studied). }\end{array}$ & Justice et al., 2003 [164] \\
\hline 5 & $\begin{array}{l}\text { Genes associated with IS: } \\
\text { Matrilin-1 (MATN1) gene polymorphism, 1p35 }\end{array}$ & $\begin{array}{l}\text { Population of } 81 \text { trios (daughter/son affected by } \\
\text { IS and both parents). }\end{array}$ & Montanaro et al., 2006 [155] \\
\hline 6 & $\begin{array}{l}\text { Genes associated with IS: } \\
\text { Matrilin-1 (MATN1), } \\
\text { rs1149048, 1p35 } \\
\text { Association with AIS susceptability }\end{array}$ & $\begin{array}{l}222 \text { cases }(90 \% \text { female }) \\
750 \text { controls ( } 88 \% \text { female) } \\
\text { adolescents } \\
\text { Chinese population }\end{array}$ & Chen et al., 2009 [156] \\
\hline 7 & $\begin{array}{l}\text { Genes associated with IS: } \\
\text { Matrilin-1 (MATN1), } \\
\text { rs 1065755, 1p35 } \\
\text { Association with curve type }\end{array}$ & $\begin{array}{l}166 \text { cases }(80 \% \text { female }) \\
126 \text { controls ( } 100 \% \text { female }) \\
\text { Adolescents } \\
\text { Korean population }\end{array}$ & Bae et al., 2012 [158] \\
\hline 8 & $\begin{array}{l}\text { Genes associated with IS: } \\
\text { Matrilin-1 (MATN1) } \\
\text { Association with curve severity and decrease of plasma } \\
\text { mtrilin-1 level }\end{array}$ & $\begin{array}{l}25 \text { cases (AIS) } \\
25 \text { controls } \\
\text { Chinese population }\end{array}$ & Wang et al. 2009 [157] \\
\hline 9 & $\begin{array}{l}\text { Genes associated with IS: } \\
\text { G-protein-coupled receptor } 126 \text { (GPR126), rs6570507, } \\
6 \mathrm{q} 24.1\end{array}$ & $\begin{array}{l}1819 \text { cases (AIS) } \\
25934 \text { controls } \\
\text { Japanese population, } \\
743 \text { cases (AIS) } \\
1209 \text { controls } \\
\text { Chinese Han population, } \\
447 \text { cases (AIS) } \\
437 \text { controls } \\
\text { European ancestry population }\end{array}$ & Kou et al., 2013 [162] \\
\hline 10 & $\begin{array}{l}\text { Genes associated with IS: } \\
\text { CHD7 gene polymorphism, } \\
8 \mathrm{q} 12\end{array}$ & $\begin{array}{l}\text { Genome-wide scan follow-up study of } 52 \\
\text { families with history of IS (130 affected } \\
\text { individuals). }\end{array}$ & Gao et al., 2007 [154] \\
\hline 11 & $\begin{array}{l}\text { Genes associated with IS: } \\
\text { Melatonin receptor 1B gene (MTNR1B), } \\
\text { rs4753426, } \\
\text { 11q21-q22 }\end{array}$ & $\begin{array}{l}\text { Initial screening ( } 472 \text { cases and } 304 \text { controls), } \\
\text { and separate replication test ( } 342 \text { cases and } 347 \\
\text { controls) }\end{array}$ & Qui et al., 2007 [71] \\
\hline 12 & $\begin{array}{l}\text { Genes associated with IS: } \\
\text { Estrogen receptor } \alpha \text { gene } \\
\text { XbaI, 6q25.1 (association with curve severity) }\end{array}$ & 304 girls with IS were tested. & Inoue et al., 2002 [167] \\
\hline 13 & $\begin{array}{l}\text { Genes associated with IS: } \\
\text { Estrogen receptor } \alpha(\mathrm{ER} \alpha) \text { gene } \\
\text { XbaI, 6q25.1 ( may be associated with a risk of AIS) }\end{array}$ & $\begin{array}{l}202 \text { cases } \\
174 \text { controls }\end{array}$ & Wu et al., 2006 [168] \\
\hline 14 & $\begin{array}{l}\text { Genes associated with IS: } \\
21 \text { candidate genes on chromosomes } 6 \text { and } 10\end{array}$ & 5 families with triple IS spine deformities & Marosy et al., 2010 [180] \\
\hline 15 & $\begin{array}{l}\text { Genes associated with IS: } \\
\text { Estrogen receptor } \alpha(\mathrm{ER} \alpha) \text { gene, } \\
6 \mathrm{q} 25.1\end{array}$ & $\begin{array}{l}147 \text { cases ( } 53 \% \text { AIS, } 47 \% \text { unaffected sisters) } \\
104 \text { controls (no AIS) } \\
\text { Age } 13-19 \text { years }\end{array}$ & Esposito et al., 2009 [125] \\
\hline
\end{tabular}


TABle 1: Continued.

\begin{tabular}{|c|c|c|c|}
\hline$\#$ & Identified Genes & Population tested & Published by \\
\hline 16 & $\begin{array}{l}\text { Genes associated with IS: } \\
\text { Calmodulin 1 (CALM1) gene } \\
\text { Melatonin receptor 1B (MTNR1B) gene, rs1562444, } \\
\text { 11q14.3 }\end{array}$ & $\begin{array}{l}30 \text { AIS cases ( } 6 \text { male, } 24 \text { female) } \\
30 \text { controls (age- and gender-matched) } \\
\text { Chinese population }\end{array}$ & Zhuang et al., 2007 [201] \\
\hline 17 & $\begin{array}{l}\text { Genes associated with IS: } \\
\text { Estrogen receptor } 1 \text { (ESR1) gene rs2234693, 6q25.1; }\end{array}$ & $\begin{array}{l}67 \text { cases (double curve patients) } \\
100 \text { nonscoliotic controls }\end{array}$ & Zhao et al., 2008 [170] \\
\hline 18 & $\begin{array}{l}\text { Calmodulin } 1 \text { (CALM1) gene: } \\
\text { rs12885713, rs5871, } \\
\text { 14q24-q31 }\end{array}$ & $\begin{array}{l}67 \text { cases (double curve patients) } \\
100 \text { nonscoliotic controls } \\
100 \text { AIS cases } \\
100 \text { Controls }\end{array}$ & Zhao et al., 2008 [170] \\
\hline 19 & $\begin{array}{l}\text { Genes associated with IS: } \\
\text { Estrogen receptor } \beta \text { gene }-458 \mathrm{~T}>\mathrm{C} \text { site polymorphisms } \\
\text { of } 14 \mathrm{q} 23.2 \text {. } \\
\text { Association with AIS in females and with curve severity. }\end{array}$ & $\begin{array}{l}218 \text { cases ( } 176 \text { female; } 42 \text { male) } \\
\text { with AIS } \\
140 \text { healthy controls. }\end{array}$ & Zhang et al., 2009 [172] \\
\hline 20 & $\begin{array}{l}\text { Genes associated with IS: } \\
\text { G-protein coupled estrogen receptor } 1 \text { (GPER1), } \\
\text { rs3808351, rs10269151, 426655s3, } \\
7 \text { p22.3 } \\
\text { Association with curve severity }\end{array}$ & $\begin{array}{l}389 \text { cases ( } 336 \text { female; } 53 \text { male }) \\
338 \text { controls ( } 289 \text { female; } 49 \text { male) } \\
\text { Age: } 10-19 \text { years } \\
\text { Chinese Han population }\end{array}$ & Peng et al., 2012 [174] \\
\hline 21 & $\begin{array}{l}\text { Genes associated with IS: } \\
\text { D17S947-D17S798 } \\
\text { 17p11 }\end{array}$ & $\begin{array}{l}\text { A three-generation family of Italian ancestry } \\
\text { that included } 11 \text { members affected by IS } \\
\text { Genome scanning was performed with } 358 \\
\text { microsatellite markers. }\end{array}$ & $\begin{array}{l}\text { Baghernajad Salehi et al., } \\
\qquad 2002[181]\end{array}$ \\
\hline 22 & $\begin{array}{l}\text { Genes associated with IS: } \\
\text { The osteoprotegerin gene } 1181 \mathrm{G} \rightarrow \text { C polymorphism } \\
\text { was associated with the bone mineral density of the } \\
\text { lumbar spine in females with AIS, } 8 \mathrm{q} 24 \text {. }\end{array}$ & 198 females with AIS were tested. & Eun et al., 2009 [182] \\
\hline 23 & $\begin{array}{l}\text { Genes associated with IS: } \\
\text { The tryptophan hydroxylase (TPH1) rs10488682, } \\
\text { 11p15.1. } \\
\text { Association with susceptibility to AIS }\end{array}$ & $\begin{array}{l}103 \text { AIS patients }\left(\text { Cobb angle }>30^{\circ}\right) \text {, and } 107 \\
\text { nonscoliotic controls. All subjects were Han } \\
\text { Chinese } 10-20 \text { years of age. }\end{array}$ & Wang et al., 2008 [183] \\
\hline 24 & $\begin{array}{l}\text { Genes associated with IS: } \\
\text { The tryptophan hydroxylase (TPH1), } \\
\text { rs10488682, 11p15.1. } \\
\text { The estrogen receptor } \alpha(\mathrm{ER} \alpha) \\
\text { rs9340799, 6q25.1 } \\
\text { Association with cure progression and success of brace } \\
\text { treatment }\end{array}$ & $\begin{array}{l}312 \text { AIS cases ( } 90 \text { progressive, and } 222 \text { no } \\
\text { progression) } \\
\text { Brace treatment } \\
\text { Chinese population }\end{array}$ & Xu et al., 2011 [30] \\
\hline 25 & $\begin{array}{l}\text { Gene associated with IS: } \\
\text { 5-hydroxytryptamine (serotonin) receptor A (HTR1A), } \\
\text { rs6294, 5q12.3 }\end{array}$ & $\begin{array}{l}103 \text { AIS cases } \\
108 \text { controls (age- and gender-matched) } \\
\text { Chinese population }\end{array}$ & Wang et al., 2010 [199] \\
\hline 26 & $\begin{array}{l}\text { Genes associated with IS: } \\
\text { Fibrillin } 3 \text { (FBN3), rs35579498, rs7257948 } \\
19 \text { p13 } \\
\text { Association with curve occurrence and progression in } \\
\text { AIS }\end{array}$ & $\begin{array}{l}273 \text { AIS patients, aged } 10-18 \text { years } \\
287 \text { control-healthy age-matched female } \\
\text { adolescents. }\end{array}$ & Cao et al., 2008 [166] \\
\hline 27 & $\begin{array}{l}\text { Gene associated with IS: } \\
\text { Metalloproteinase-3 (MMP3) promoter gene } \\
\text { 11q22.3 }\end{array}$ & $\begin{array}{l}53 \text { patients with AIS and } 206 \text { nonscoliotic } \\
\text { controls. Age was not specified. }\end{array}$ & Aulisa et al., 2007 [184] \\
\hline 28 & $\begin{array}{l}\text { Gene associated with IS: } \\
\text { Metalloproteinase-9 (MMP9), rs2250889, 20q13.12 }\end{array}$ & $\begin{array}{l}190 \text { AIS cases } \\
190 \text { controls } \\
\text { Female } \\
\text { Chinese Han population }\end{array}$ & Huang et al., 2011 [198] \\
\hline 29 & $\begin{array}{l}\text { Gene associated with IS: } \\
\text { Interleukin-6 ( IL6) promoter gene } \\
\text { 7p21-p15 }\end{array}$ & $\begin{array}{l}53 \text { patients with AIS and } 206 \text { nonscoliotic } \\
\text { controls. Age was not specified. }\end{array}$ & Aulisa et al., 2007 [184] \\
\hline
\end{tabular}


TABle 1: Continued.

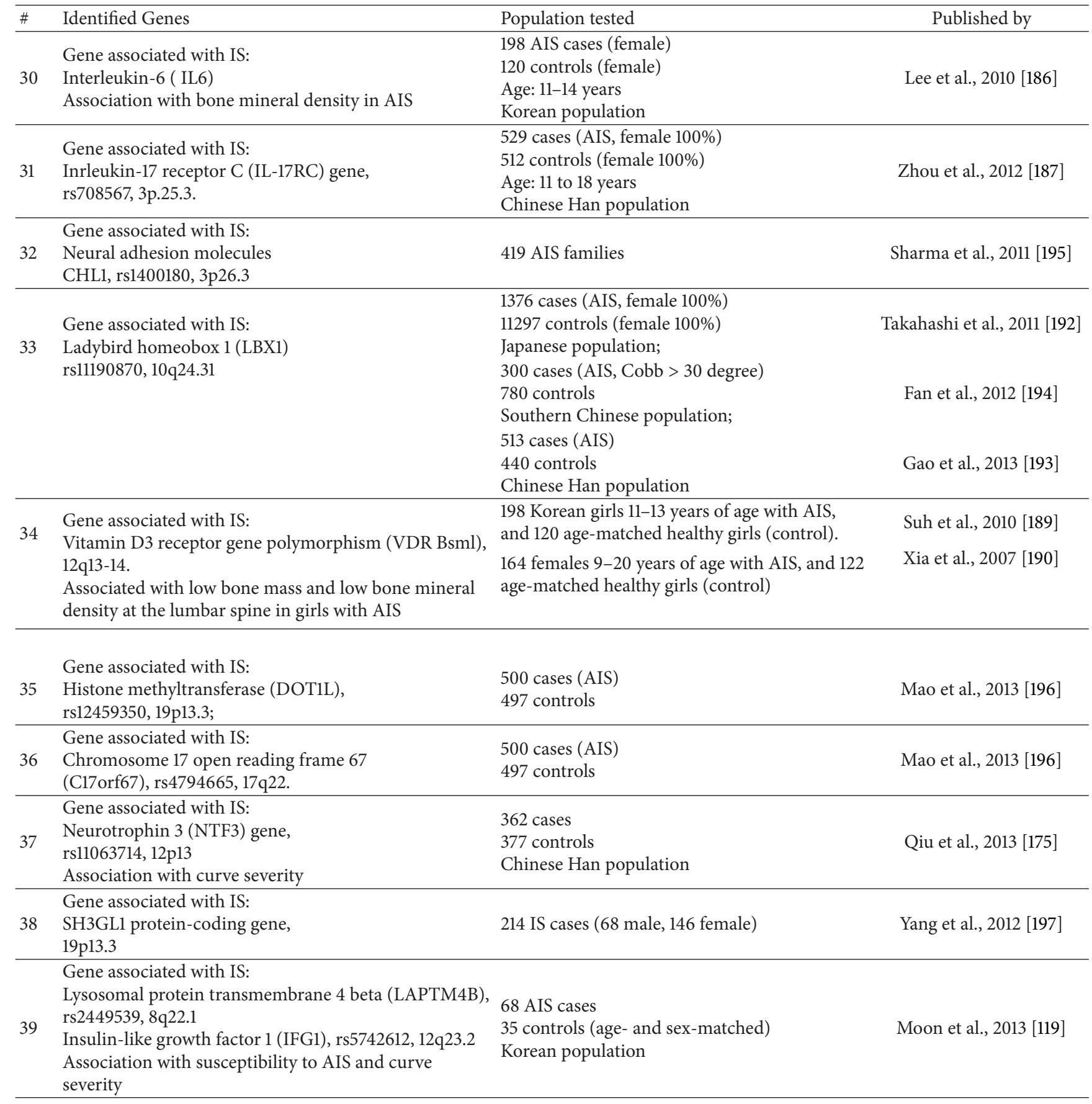

a polymorphism of the promoter of melatonin receptor $1 \mathrm{~B}$ gene (MTNR1B) that was revealed in Chinese population [71] corresponding with previously revealed impairment of the melatonin transduction pathway [68]. However, this result was not replicated in Japanese [152] and Caucasian [153] populations. An association of AIS was also found with the CHD7 gene (chromodomain helicase DNA-binding protein 7 gene) [154]. Splicing mutations within coding exons of CHD7 have been identified in a majority of patients with CHARGE syndrome (coloboma of eye, heart defects, atresia of the choane, retardation of growth and/or development, genital, and/or urinary abnormalities, and ear abnormalities and deafness). It was hypothesized that milder variants of the CHD7 polymorphism could underlie IS susceptibility [154]. A link between matrilin-1 gene polymorphism (MATN1) and AIS has been found in European [155], Chinese [156, 157], and Korean [158] populations but was not replicated in Japanize population [159]. Wang et al. [157] noted that MATN1 polymorphism in AIS corresponds with decrease of plasma matrilin-1 levels. Matrilin-1 was previously named cartilage 
matrix protein (CMP) and is mostly found in cartilage. CMP is a bridging molecule that connects matrix components in cartilage to form an integrated matrix filamentous network [160]. Biglycan/matrilin-1 or decorin/matrilin-1 complex acts as a linkage between collagen VI microfibrils and aggrecan or alternatively collagen II [161]. Thus, a defect of CMP/matrilin-1 molecules may cause a significant impairment of the cartilage ultrastructure. Genetic variants of GPR126 gene showed association with AIS in Japanese, Chinese Han, and European-ancestry populations [162]. This gene encodes G-protein-coupled receptor 126 required for normal differentiation of promyelinating Schwann cells and axons myelination [163]. This gene is highly expressed in cartilage [162] and probably is involved in regulation of the cAMP level in cells [163] and development of spinal cord [162]. Data on the role of X chromosome in the pathogenesis of IS are contradictory. Justice et al. [164] reported on the association between familial IS and a polymorphism of $\mathrm{X}$ chromosome particularly GATA172D05. This region includes several loci whose functions have been related to cellular interactions within the extracellular matrix of neural tissue and a chordin-like protein, which is known to be essential to the correct patterning of the zebrafish axial skeleton through bone morphogenetic proteins signaling. The genes that encode two of the collagen type IV alpha chains have also been mapped to this region. However, evidence of the $\mathrm{X}$ chromosome polymorphism was only found in $15 \%$ of the studied families, which had X-linked dominant inheritance. Chan et al. [165] did not find any link between the Xchromosome polymorphism and IS but revealed a significant association between the abnormal phenotype of the distal short arm of chromosome 19p13.3 and AIS. Within this region, there are more than 70 possible genes expressed in chondrocytes, osteoclasts, muscles, or tendon that could be potential candidate genes for IS. In particular, fibrillin-3 gene is in this region. Polymorphisms of this gene may be associated with body height of the AIS patients, or occurrence and progression of AIS [166]. Data on the association of the estrogen receptor gene polymorphism with susceptibility to IS are contradictory. Inoue et al. [167] reported on the association between estrogen receptor $\alpha(\mathrm{ER} \alpha)$ gene polymorphism and curve severity. Wu et al. [168] confirmed the association between the ER $\alpha$ gene polymorphism and AIS. Xu et al. [30] suggested that the ER $\alpha \mathrm{SNP}$ is associated with curve progression. These findings could not be replicated by Tang et al. [169]. However, Zhao et al. [170] reported on statistically significant associations between polymorphism of the ER $\alpha$ and calmodulin-1 (CALM1) [171] genes with susceptibility to AIS and the type of scoliotic curvature. Esposito et al. [125] identified four ER $\alpha$ gene polymorphisms in AIS. In addition, Zhang et al. [172] reported an association between SNP of the estrogen receptor $\beta(\mathrm{ER} \beta)$ gene with AIS susceptibility and curve type and severity in females. On the contrary, Takahashi et al. [173] did not find any association between these estrogen receptor genes and susceptibility to AIS or curve severity in the Japanese population. It was reported that polymorphism of G-protein-coupled estrogen receptor (GPER) [174] and neurotropin 3 (NTF3) [175] genes has significant association with curve severity in AIS in Chinese Han population. These findings were not replicated in Japanese population [176]. It has been proposed that a disturbance in proteoglycan (PG) synthesis and formation in the vertebral growth plate is a basic cause of IS. It was suggested that aggrecan gene expression was significantly decreased in cultivated chondroblasts from patents with IS [177]. However, Marosy et al. [178] showed the lack of an association between the aggrecan gene and familial IS, but other potential candidate genes were revealed on 15q25-26. To note, fibrillin-1 (FBN1) gene, which is associated with Marfan syndrome, is located nearby (at15q21.1). Nevertheless, an association between a polymorphism of the FBN1 gene and AIS was not found [179]. Twenty-one candidate genes on chromosomes 6 and 10 were found in families with triple IS spine deformities [180]. Salehi et al. [181] reported on the link between familial IS and 17p11 (D17S947-D17S798) gene polymorphism. These protein genes play a role in glycoproteoglycan sulfation, the process that is important for the organization of osteoligamentous structures. A significant association was found between the osteoprotegerin (OPG) gene polymorphism and bone mineral density of the lumbar spine in female with AIS [182]. OPG is a cytokine that is a member of the tumor necrotic factor superfamily, which inhibits the production of osteoclasts and thus indirectly stimulates bone modeling. The OPG gene polymorphisms may indirectly stimulate osteoclastogenesis and bone remodeling. Wang et al. [183] have found a significant association between a tryptophan hydroxylase (TPH1) gene polymorphism and susceptibility to AIS in Chinese population. Xu et al. [30] suggested that the TPH1 gene SNP is associated with the risk of curve progression. The TPH1 is involved in the synthesis of the neurotransmitter serotonin from tryptophan, which then can be transformed to melatonin. Thus a polymorphism of this gene can contribute to reduced synthesis of both serotonin and melatonin. However, this SNP was not replicated in Japanese [159] and Caucasian [153] populations. It was shown that a MMP-3 promoter gene polymorphism is significantly associated with AIS [184]. But this finding was not replicated in Chinese population [185]. The MMP-3 relates to the matrix metalloproteinase family that is involved in the breakdown of extracellular matrix, in particular degrading of fibronectin, collagens III, IV, IX, and X, and cartilage proteoglycans and tissue remodeling, as well as in disease processes, such as arthritis and metastasis. An IL-6 (interleukin 6) promoter gene polymorphism was also reported as having association with AIS [184], in particular, bone mineral density in AIS patients [186]. The IL-6 is a cytokine with a wide variety of biological functions. It plays an essential role in the final differentiation of B-cells into Ig-secreting cells. This protein is primarily produced at sites of acute and chronic inflammation, where it induces a transcriptional inflammatory response through corresponding receptors. This suggests an involvement of the immune system and inflammatory processes in the pathogenesis of AIS. However, no link between IL-6 and AIS was found in Chinese population [185]. Instead, in Chinese population, an association between the interleukin-17 receptor C (IL-17RC) gene polymorphism and the susceptibility to AIS was shown [187]. The Il-17RC promotes the production of proinflammatory cytokines such as 
TNF $\alpha$, IL-1 $\beta$, and IL-6 [187]. Mórocz et al. [188] demonstrated that SNP of such genes as BMP4, Il6, leptin, MMP3, and MTNR1B may not have significant association with AIS, if they were tested separately. However, combinations of these genes SNP have significant association with susceptibility to AIS in the Hungarian population. It was reported that a vitamin $\mathrm{D}$ receptor (VDR) gene SNP is associated with decreased bone mineral density, in particular of the lumbar spine in girls with AIS (Korean population) [189, 190]. The VDR are expressed in cells of different tissues, including bone and the parathyroid gland. Vitamin D is involved in the regulation of parathormone secretion [137]. Thus, this finding corresponds with decreased levels of parathormone revealed in girls with IS [130]. However, Chen et al. [191] did not find any association between the VDR gene polymorphism and bone mineral density in Chinese AIS girls. Variants near LBX1 gene encoding ladybird homeobox-1 have significant link with AIS in Japanese [192] and Chinese populations $[193,194]$. The LBX1 encodes transcription factor required for the development of interneurons in the dorsal horn of the spinal cord and migration and development of muscle precursor cells for limb muscles, diaphragm, and hypoglossal cord [163]. The CHL1 gene was recognized as a candidate gene linked with susceptibility to AIS [195]. This gene encodes family of neural cell adhesion molecules that may be involved in signal transduction pathways [163]. Polymorphism of other two genes DOT1L encoding histone methyltransferase and C17orf67 (chromosome 17 open reading frame 67) are shown as linked with susceptibility to AIS [196]. The histone methyltransferase DOT1L plays a complex role in cartilage biology and may be associated with osteoarthritis $[163,196]$. Characteristics of the protein that is encoded by C17orf67 are not studied well [196]. Other genes SNPs that have been reported as having association with AIS are SH3GL1 [197], LAPTM4B [119], IFG1 [119], MMP9 [198], HTR1A [199], and TIMP2 [200].

Axial Biotech Inc. [202] has developed a test to identify patients with low risk of scoliotic curve progression using 53 genetic markers. Published results suggested that the test has high negative predictive value (97\%$100 \%)$, but low positive predictive value (8\%-25\%) [203]. It means that cases with high risk of scoliotic deformity progression can be underdiagnosed by this test. The test showed lack of predictive value in Japanese population [162].

In summary, published data concerning association between gene polymorphism and AIS are heterogeneous and have limited replicability. We may assume that AIS may have different patterns of genetic determinants depending on the ethnic population. Combinations of these determinants probably predispose individuals to the disease. Defects in the molecular structure of different proteins, caused by genetic polymorphism, may lead to different ultrastructural features at different systems and tissues of the body, including the CNS, hormonal regulation, the immune system, connective tissue, bone, cartilage, ligaments, and muscles, which form specific conditions for the spine curve triggering and progression.
3.11. Biomechanical Factors. Biomechanical factors play a significant role in the progression of scoliosis. A vicious cycle of asymmetrical loading has been hypothesized to explain this effect. It was suggested that increased compression on the concave side of the curve decelerates growth, while reduced loading on the convex side accelerates growth according to the Hueter-Volkmann's law and creates a larger deformity [1-3, 204, 205]. Today, these phenomena may be explained by the effects of mechanotransduction, which include intracellular and extracellular signaling factors such as mechanosomes, corresponding genes, nitric oxide (NO), cAMP, gene encoding enzymes, bone morphogenic proteins (BMP) 1 and 4, and growth factors such as IGF-1, IGF2 , vascular endothelial growth factor (VEGF), and transforming growth factor- $\beta_{1}$ (TGF- $\beta_{1}$ ), which act via autocrine and paracrine mechanisms [206-208]. Signal transduction pathways such as IGF-1 may interact with estrogen in the proliferative response to mechanical strain [209]. An interaction between different anabolic intracellular pathways may enhance the upregulation of these signaling pathways, ultimately leading to the cellular response on mechanical loading [209]. Experimental studies show that for normal bone modeling, bone strain should not exceed $2 \mathrm{MPa}(\mathrm{MPa}-$ megapascal $=10^{6}$ newtons $/ \mathrm{m}^{2}$ ). If mechanical strain exceeds $60 \mathrm{MPa}$, then microscopic fatigue damage and a decrease in bone growth may occur [210]. Unfortunately, there is a paucity of data related directly to the quantitative in vivo assessment of strain at the surface of the human vertebrae endplates and the association between strain and the morphological and ultrastructural characteristics of the vertebrae endplates and discs in patients with IS, especially in the upright position [211, 212]. Meir et al. [213] reported results of hydrostatic pressure measured across the IVD in recumbent anaesthetized scoliotic patients during surgery. It was shown that intradiscal pressure and stress in scoliotic discs are abnormal and have higher hydrostatic pressure $(0.25 \mathrm{MPa})$ than those measured in nonscoliotic discs $(<0.07 \mathrm{MPa})$. Stress in the concave annulus was greater than in the convex annulus, indicating asymmetric loading. The authors noted that without the presence of muscle activity and horizontal positioning of the patients, it is difficult to explain this finding from the point of view of the "vicious cycle" hypothesis.

\section{Morphological and Ultrastructural Features of Scoliotic IVD and VEPh}

4.1. Disc Cells and Extracellular Matrix Features. It was suggested that asymmetry in mechanical loading is the main factor that leads to morphological changes in scoliotic IVD and VEPh. The effects of mechanotransduction are important components in the response of bone and cartilage to mechanical load. Mechanotransduction pathways involve specific cytoskeletal components, such as vimentin and actin. Johnson and Roberts [214] compared the presence of such cytoskeletal components as phalloidin-labeled filamentous actin (F-actin) and vimentin in the disc cells of patients with scoliosis, in subjects without disc pathology, and in subjects with degenerative disc diseases. F-actin-positive cells 
appearing stellate or dendritic were observed in the outer annulus of scoliotic discs. Such cells were not seen in the outer annulus fibrosus of nonscoliotic or degenerative discs. F-actin appeared more prominent on the convex side of the scoliotic curve than on the concave side, not corresponding with the putative response. The authors suggested that cells in scoliotic discs tend to change phenotype in comparison with nonscoliotic discs. This study had considerable limitations (see Table 2) necessitating further investigation. Ford et al. [215] used transmission electron microscopy and immunostaining markers and revealed that cells of scoliotic discs exhibited a healthy appearance and abundant endoplasmic reticulum, which indicated a high level of secretory activity, while proliferative activity was decreased. Specimens for this study were taken from the anterior annulus of the discs, thus asymmetrical load probably did not impact the results.

Bertram et al. [216] demonstrated that chondrocytetypical extracellular-matrix gene expression was higher in scoliotic IVDs than in the normal spine. Histological analysis showed mild degeneration of the IVDs, including minor granular changes, clefts and tears, and mucoid matrix degeneration that was accompanied with accelerated anabolic matrix metabolism, which included higher extracellular matrix gene expression of collagen type II, biglican, collagen type XI, collagen type XII, aggrecan, lumican, chondromodulin-I precursor, and decorin. Antoniou et al. [217] revealed a decrease in the total collagen content in the scoliotic annulus and endplate regions. Glycosaminoglycan content was also decreased in the scoliotic endplates and nucleus regions. However, the total protein level was significantly elevated. Water content was considerably lower in the scoliotic annulus and endplate regions. Levels of marker for type II collagen synthesis were higher in the nucleus, annulus, and endplate regions of scoliotic discs than in the corresponding regions of normal discs. By contrast, the presence of total denaturated collagen was significantly elevated in the nucleus of normal tissue as compared to scoliotic tissue. The authors suggested that these scoliotic changes are due to an altered and ineffective synthetic response to a pathologic mechanical environment. These results correspond with the finding that proteoglycan molecules in patients with AIS contained more protein and less carbohydrates than the proteoglycans of normal tissue [223]. It was shown that a chondroadherin level was lower at the concave site of the scoliotic discs than at the convex side, suggesting changes in matrix homeostasis [222]. He et al. [224] showed that patients with AIS had significantly more type I and type II collagen on the convex side of IVDs compared with the concave side. Similar results had previously been obtained by Roberts et al. [221]. They also pointed out that staining patterns for collagen types III, VI, and IX were different in scoliotic IVDs in comparison with nonscoliotic IVDs [221]. Gene expression of type X collagen, which was associated with hypertrophic changes and cartilage mineralization, was revealed mainly at the concave side of the apical disc in patients with IS [225]. Yu et al. [219] showed that in scoliotic IVD (AIS and neuromuscular scoliosis), the elastic fibers were sparse, and collagen and elastic fiber networks were disorganized with a loss of lamellar structure. Cell clusters, a typical degenerative feature, were seen in scoliotic discs but not in age-matched controls. However, based on these data it is impossible to determine whether the finding of a sparse elastic fiber network in the IVD of patients with IS is a primary or secondary factor. Akhtar et al. [220] showed that in the degenerated regions of scoliotic IVDs there was a disruption of collagen and elastic fibers accompanied by losses of keratan sulfate (KS) proteoglycan, and degeneration of elastic fibers that was accompanied by the loss of $\alpha$-elastin. KS-bearing proteoglycan (lumican or fibromodulin) is closely associated with the lamellar organization of collagen fibers and elastic fibers in the IVD. It was hypothesized that impaired cellular metabolism of lumican and/or fibromodulin can contribute to the development of scoliotic spine deformity. As specimens in this study were taken from the medial parts of the IVDs, asymmetrical axial load did not impact the results. Thus, this finding probably reflects systemic features of scoliotic cells. Stern et al. [218] demonstrated significantly higher synthesis of deoxyribonucleic acid, proteoglycan, and hydroxyproline in cells from scoliotic disks in comparison with cells taken from osteochondrotic and herniated discs. There was no evidence of enhanced senescence (physiologic aging) [226] or apoptosis [227] of IVD cells in patients with IS in comparison to those with neuromuscular scoliosis or disc degenerative diseases. Unfortunately, a comparison between IS disc cells and normal age-matched disc cells was not performed in these studies. IVD degeneration correlated with the level of matrix metalloproteinases (MMP), which contribute to extracellular matrix degrading and tissue remodeling and are involved in inflammatory reactions [228]. The MMP level was asymmetric and prevailed at the convex site of IVDs in patients with AIS [228].

In summary, the most important features of the IVD in IS are as follows: (1) increased synthetic and decreased proliferative cells activity; (2) changes and asymmetry of collagen synthesis and degrading; (3) increased synthesis of proteins; (4) impairment of collagen turnover that results in failure of the synthesized extracellular matrix components to organize into a normal lamellar structure; (5) decreased water content and increased hydrostatic pressure. Initial genetic determinants probably comprise the basis of these IVD features, which may then be significantly modulated by the mechanical environment and other factors during disease manifestation. Overall these microstructural features decrease the ability of scoliotic discs to tolerate load and contribute to disc wedging and Schmorl's nodes occurrence. This is more evident at the apex of the lumbar curvature where load is higher, while wedging of the vertebral body prevails at the apex of the thoracic curvature [204, 205, 229].

4.2. Vertebrae Endplate Features. Roberts et al. [221] pointed out that the prevalence and extent of calcification in the cartilage endplate of the scoliotic specimens were the most striking finding of their study. Calcification appeared to start at one or both ends of the individual cells before it encompassed the cell and became more widespread throughout the matrix. It was prominent in the cartilage endplate nearest the anterior rim. Calcification may also expand into the IVD. 
TABLE 2: Morphological and ultrastructural studies.

\begin{tabular}{|c|c|c|c|c|c|}
\hline \# & Findings & Objects/Materials & Method & $\begin{array}{l}\text { The main limitations of the } \\
\text { study }\end{array}$ & Authors \\
\hline 1 & $\begin{array}{l}\text { F-actin-positive cells were } \\
\text { observed in the outer } \\
\text { anulus of scoliotic discs and } \\
\text { appeared stellate or } \\
\text { dendritic, rather than } \\
\text { bipolar and fibroblastic. } \\
\text { F-actin appeared more } \\
\text { prominent on the convex } \\
\text { side of the scoliotic curve } \\
\text { than on the concave side }\end{array}$ & $\begin{array}{l}\text { Specimens of } 13 \text { human } \\
\text { intervertebral discs: } \\
\text { Normal-3; } \\
\text { Low back pain-4; } \\
\text { Spondylolisthesis-3; } \\
\text { Scoliosis-3 }\end{array}$ & $\begin{array}{l}\text { Morphology of IVD cells } \\
\text { was examined using } \\
\text { confocal microscopy and } \\
\text { labeling of such } \\
\text { cytoskeleton components } \\
\text { as F-actin and vimentin. }\end{array}$ & $\begin{array}{l}\text { (1) Small amount of } \\
\text { specimens. } \\
\text { (2) Statistical analysis was } \\
\text { not performed } \\
\text { (3) Studied subjects were } \\
\text { not matched by age and } \\
\text { gender. } \\
\text { (4) Specimens were not } \\
\text { matched by the spine level. } \\
\text { (5) Type of scoliosis was } \\
\text { not specified }\end{array}$ & $\begin{array}{l}\text { Johnson and } \\
\text { Roberts, } 2003 \\
{[214]}\end{array}$ \\
\hline 2 & $\begin{array}{l}\text { Cells from anterior anulus } \\
\text { of scoliotic discs had } \\
\text { increased secretory activity } \\
\text { and decreased proliferative } \\
\text { activity. }\end{array}$ & $\begin{array}{l}\text { The anterior annulus tissue } \\
\text { of discs: } \\
\text { Scoliotic-5 (aged 16-26); } \\
\text { Degenerative-5 (aged } \\
\text { 43-56); } \\
\text { Prolapsed discs-5 (aged } \\
\text { 33-52) }\end{array}$ & $\begin{array}{l}\text { Histology and transmission } \\
\text { electron microscopy with } \\
\text { immunostaining markers. }\end{array}$ & $\begin{array}{l}\text { (1) Subjects gender was not } \\
\text { taken into consideration. } \\
\text { (2) Statistical analysis was } \\
\text { not performed. }\end{array}$ & $\begin{array}{l}\text { Ford et al., } \\
2002[215]\end{array}$ \\
\hline 3 & $\begin{array}{l}\text { Morphologic disc } \\
\text { degeneration in IS was } \\
\text { associated with stronger } \\
\text { anabolic matrix } \\
\text { metabolism. } \\
\text { Higher mRNA expression } \\
\text { of extracellular matrix } \\
\text { molecules like collagen II, } \\
\text { aggrecan, biglican, decorin, } \\
\text { lumical, and } \\
\text { chondromodulin was } \\
\text { revealed. }\end{array}$ & $\begin{array}{l}\text { Study groups: } \\
\text { Idiopathic scoliosis (11 } \\
\text { female and } 5 \text { male aged } \\
10-22 \text { years); } \\
\text { Patients with acute trauma } \\
\text { ( } 2 \text { female, and } 5 \text { male aged } \\
28-55) ; \\
\text { Autopsy control } \\
\text { adolescents ( } 4 \text { male and } 4 \\
\text { female aged } 8 \text { to } 17 \text { years); } \\
\text { Autopsy control adults ( } 7 \\
\text { male and } 3 \text { female aged } \\
47-77 \text { years) }\end{array}$ & $\begin{array}{l}\text { Histological examination. } \\
\text { Gene expression analysis. }\end{array}$ & $\begin{array}{l}\text { (1) Studied subjects were } \\
\text { not matched by age and } \\
\text { gender. }\end{array}$ & $\begin{array}{l}\text { Bertram et } \\
\text { al., } 2006 \text { [216] }\end{array}$ \\
\hline 4 & $\begin{array}{l}\text { Higher collagen Type II } \\
\text { synthetic levels and } \\
\text { increased total protein } \\
\text { content with no matrix } \\
\text { turnover. Scoliotic changes } \\
\text { are due to an altered and } \\
\text { ineffective synthetic } \\
\text { response to a pathologic } \\
\text { mechanical environment. }\end{array}$ & $\begin{array}{l}\text { Specimens of IVD and } \\
\text { vertebrae endplates: } \\
\text { (i) } 15 \text { scoliotic (female) } \\
\text { aged } 11-15 \text { years; } \\
\text { (ii) } 17 \text { normal control } \\
\text { subjects (no details) }\end{array}$ & $\begin{array}{l}\text { Discs and endplates were } \\
\text { analyzed for their water, } \\
\text { collagen, proteoglycan, and } \\
\text { protein content. } \\
\text { Biochemical methods were } \\
\text { used. }\end{array}$ & $\begin{array}{l}\text { (1) The scoliotic tissue was } \\
\text { analyzed mainly at the } \\
\text { convex and central side of } \\
\text { the disc where the tissue is } \\
\text { experiencing tension and } \\
\text { not compressive force } \\
\text { (2) Control group was not } \\
\text { clearly identified. }\end{array}$ & $\begin{array}{l}\text { Antoniou et } \\
\text { al., } 2001 \text { [217] }\end{array}$ \\
\hline 5 & $\begin{array}{l}\text { Cells obtained from } \\
\text { scoliotic discs showed } \\
\text { higher synthetic activity } \\
\text { than cells from } \\
\text { degenerative and herniated } \\
\text { discs. }\end{array}$ & $\begin{array}{l}\text { Studied subjects: } \\
\text { IS-6 patients (mean } \\
\text { age-24.4 years); } \\
\text { Osteochondrosis-6 } \\
\text { patients (mean age } 42.8 \\
\text { years); } \\
\text { Disc herniation-6 patients } \\
\text { (mean age } 35.2 \text { years) }\end{array}$ & $\begin{array}{l}\text { Cultures of disc cells were } \\
\text { studied. } \\
\text { Deoxyribonucleic acid } \\
\text { content, hydroxyproline } \\
\text { content, and proteoglycan } \\
\text { synthesis were determined. }\end{array}$ & $\begin{array}{l}\text { (1) Gender of the studied } \\
\text { subjects was not taken into } \\
\text { consideration. } \\
\text { (2) Studied subjects were } \\
\text { not matched by age. }\end{array}$ & $\begin{array}{l}\text { Stern et al., } \\
2004[218]\end{array}$ \\
\hline 6 & $\begin{array}{l}\text { In scoliotic discs, elastic } \\
\text { fibers were sparse, and the } \\
\text { collagen and elastic fiber } \\
\text { networks were } \\
\text { disorganized with loss of } \\
\text { lamellar structure. Cell } \\
\text { clusters (degenerative } \\
\text { feature) were seen in } \\
\text { scoliotic discs but not in } \\
\text { age-matched control discs. }\end{array}$ & $\begin{array}{l}\text { Studied subjects: } \\
\text { IS-3 female (age 12-22 } \\
\text { years); } \\
\text { Neuromuscular-3 female } \\
\text { (age } 14-16 \text { years); } \\
\text { Control-2 (1 female with } \\
\text { spinal tumor aged } 12 \text { years; } \\
1 \text { male with trauma aged } 17 \\
\text { years) }\end{array}$ & $\begin{array}{l}\text { Micrographs of the sections } \\
\text { of IVDs were examined by } \\
\text { polarized light to visualize } \\
\text { collagen organization. The } \\
\text { elastic fiber network was } \\
\text { visualized } \\
\text { immunohistechemically or } \\
\text { by histochemical staining } \\
\text { with orcein. }\end{array}$ & $\begin{array}{l}\text { (1) Small amount of cases } \\
\text { and controls. } \\
\text { (2) Statistical analysis was } \\
\text { not performed. }\end{array}$ & $\begin{array}{l}\text { Yu et al., } 2005 \\
\text { [219] }\end{array}$ \\
\hline
\end{tabular}


TABLE 2: Continued.

\begin{tabular}{|c|c|c|c|c|c|}
\hline \# & Findings & Objects/materials & Method & $\begin{array}{l}\text { The main limitations of the } \\
\text { study }\end{array}$ & Authors \\
\hline 7 & $\begin{array}{l}\text { In scoliosis, impaired } \\
\text { regulation of collagen } \\
\text { fibrillogenesis by lumican } \\
\text { or fibromodulin may result } \\
\text { in lamellar structure. }\end{array}$ & $\begin{array}{l}\text { Studied subjects: } \\
\text { IS-3 female patients ( } 13 \text {, } \\
15 \text {, and } 17 \text { years old); } \\
\text { Normal control-2 male } \\
(20,24 \text { years old })\end{array}$ & $\begin{array}{l}\text { Specimens from medial } \\
\text { (anterior, central and } \\
\text { posterior) parts of L1-L3 } \\
\text { discs were studied. } \\
\text { Ultrastructural relations } \\
\text { among keratan sulfate } \\
\text { proteoglycan, } \alpha \text {-elastin, } \\
\text { collagen fibers, and elastic } \\
\text { fibers were studied. }\end{array}$ & $\begin{array}{l}\text { (1) Small case and control } \\
\text { groups. } \\
\text { (2) Cases and controls were } \\
\text { not matched by gender and } \\
\text { age. } \\
\text { (3) Statistical analysis was } \\
\text { not performed. }\end{array}$ & $\begin{array}{l}\text { Akhtar et al., } \\
2005[220]\end{array}$ \\
\hline 8 & $\begin{array}{l}\text { Proteoglycan and water } \\
\text { content were reduced in } \\
\text { scoliotic discs, particularly } \\
\text { toward concavity of the } \\
\text { curve. The distribution of } \\
\text { some collagen types } \\
\text { differed in scoliotic discs. } \\
\text { Calcification of the } \\
\text { cartilage endplates and } \\
\text { adjacent discs was revealed } \\
\text { in scoliosis. }\end{array}$ & $\begin{array}{l}\text { Studied subjects: } \\
\text { Scoliosis-20 patients } \\
\text { including } 15 \text { with IS, } 4 \text { with } \\
\text { congenital, and } 1 \text { with } \\
\text { unknown type. Age: } 3-42 \\
\text { years (mean-14.4). Gender } \\
\text { was not indicated. } \\
\text { Control-12 subjects. Age } \\
\text { 17-83 (mean-58.1). } \\
\text { Gender was not identified. }\end{array}$ & $\begin{array}{l}\text { The morphology and } \\
\text { composition of the IVD } \\
\text { and vertebrae cartilage } \\
\text { endplates were studied }\end{array}$ & $\begin{array}{l}\text { (1) Case and controls were } \\
\text { not matched by age and } \\
\text { gender. } \\
\text { (2) Cases with IS and } \\
\text { congenital scoliosis were } \\
\text { not analyzed separately. } \\
\text { (3) Specimens were not } \\
\text { matched by the spine level } \\
\text { (T6-T10 for scoliosis; } \\
\text { L1-L5 for controls). } \\
\text { (4) Statistical analysis was } \\
\text { not performed. }\end{array}$ & $\begin{array}{l}\text { Roberts et al., } \\
1993 \text { [221] }\end{array}$ \\
\hline 9 & $\begin{array}{l}\text { A chondroadherin level } \\
\text { decreased at the concave } \\
\text { site of scoliotic discs }\end{array}$ & $\begin{array}{l}\text { Studied subjects: } \\
\text { Scoliosis (AIS) - } 7 \text { patients } \\
\text { ( } 5 \text { female and } 2 \text { male), age } \\
14-17 \text { years. } \\
\text { Control-2 nonscoliotic } \\
\text { subjects aged } 29 \text { and } 87 \\
\text { years. Gender was not } \\
\text { specified. }\end{array}$ & $\begin{array}{l}\text { Specimens from scoliotic } \\
\text { subjects were taken during } \\
\text { surgery (1 T9/T10, } 3 \text { T12/L1, } \\
\text { and } 3 \text { L1/L2 discs). } \\
\text { Control specimens were } \\
\text { obtained during autopsy } \\
\text { (2-L4/L5 discs) }\end{array}$ & $\begin{array}{l}\text { (1) Small amount of cases } \\
\text { and controls } \\
\text { (2) Cases and controls were } \\
\text { not matched by age } \\
\text { (3) Cases and control } \\
\text { specimens were not } \\
\text { matched by the spine level } \\
\text { (4) Statistical analysis was } \\
\text { not performed. }\end{array}$ & $\begin{array}{l}\text { Haglund et } \\
\text { al., 2009 } \\
{[222]}\end{array}$ \\
\hline
\end{tabular}

The author noted that most studied patients with scoliosis had not reached skeletal maturity at the time of the study. Therefore, endochondral ossification should be ongoing in epiphyseal regions, such as the cartilage endplate. Calcification of the IVD has also been described in healthy children, which resolved later in life. To note, cases and controls were not matched by age and gender in that study.

There was evidence that the proliferative and hypertrophic chondrocytes in the anterior column of AIS patients were more active than those on the posterior column [230, 231]. These features seem to be more evident in patients with AIS than those with congenital scoliosis. It has also been shown that in AIS the proliferative potential and apoptosis ratios of chondrocytes in the proliferative and hypertrophic zone in the convex side were significantly higher than in the concave side, particularly in the apical vertebral growth plate [232]. Changes in proliferative activity of chondrocytes correlated with the radiographic data of the spine deformity. However, it was unclear whether these differences in proliferation were the primary cause or were due to secondary changes. The authors suggested that these findings may be secondary and result from mechanical causes.

Expression of cell signaling factors is an important marker of cell activity. It was found that expression of transforming growth factor $\beta 1$ (TGF $\beta 1$ ) and basic fibroblast growth factor (bFGF) was higher on the concave side in patients with AIS, while expression of the core protein of proteoglycan was higher on the convex side $[233,234]$. TGF $\beta$ relates to the family of bone morphogenetic proteins and regulates growth and proliferation of cells. TGF $\beta 1$ acts through corresponding receptors and mediates a transcriptional activation. In particular, it regulates collagen type II gene expression which suggests an important role in the repair process during early IVD degeneration. However, this effect depends on whether the cells are fully differentiated or undergoing phenotype loss [235]. To note, melatonin stimulates TGF $\beta 1$ activity [236], thus, an impairment in melatonin signaling may modify this effect in patients with IS. FGFs are a family of growth factors involved in wound healing and embryonic development. One of the most important functions of bFGF is the promotion of endothelial proliferation and angiogenesis [237]. But it is also known that excessive release of bFGF during loading and/or injury of the cartilage matrix may contribute to the onset or progression of osteoarthritis. This pathological role may be related to the ability of bFGF to decrease proteoglycan synthesis and to antagonize the activity of anabolic growth factors in cartilage such as IGF-1 and BMP-7 and stimulate matrix metalloproteinase-13, which is a matrix catabolic cartilage-degenerative enzyme [238]. 
Experimental data suggest that melatonin modulates the effects of bFGF and inhibits bFGF gene expression [239]. Administration of melatonin reduced the cartilage endplate vascularity of degenerated intervertebral discs. It may have a stimulative effect on bone formation. However, bFGF and TGF $\beta 1$ are involved in the mechanisms of mechanotransduction. Thus, the effects of mechanotransduction and impairment of melatonin signaling pathways may overlap, making endplate cells more sensitive to mechanical impact. Increases in (bFGF) correspond to the results of inflammatory endplate changes, which are present at the concave apex in patients with AIS [229].

The majority of published data in the field of morphology and ultrastructure of IVD and VEPh in IS have serious limitations that make interpretation of the results difficult. Some of these limitations are summarized in Table 2. There is also a lack of data on the morphological and ultrastructural appearance of in infantile and juvenile IS.

\section{Discussion}

Our literature review supports the theory of a multifactorial etiology for IS. The different hypotheses highlight the diverse aspects of the etiopathogenetic mechanisms. Some of these mechanisms may be regarded as risk factors with different contributions in each disease case. This approach allows us to explain the wide variability of the clinical appearance in IS and hopefully predict disease occurrence and progression in future. Combinations of different genetic determinants are likely the main etiologic factor, which can be classified in two main groups. First, polymorphism of genes that may cause cell signaling impairments in different tissues, including bone and cartilage, and changes in hormonal regulation. Theoretically, combinations of these genetic features may contribute to such clinical appearances as skeletal and spinal overgrowth, decrease in bone mineral density, delay of skeletal maturity and spine slenderness, and dysfunction of the central and autonomic nervous systems which predispose occurrence and progression of the scoliotic spine curvature. The second groups of genetic determinants are likely associated with systemic defects in the structure of connective tissue and cartilage and may be with changes in embryogenesis. They may be linked with such clinical appearances as instability of spine, body asymmetry, and some concomitant congenital abnormalities. There is a high probability that polymorphisms of other genes that are associated with IS will be identified in the future. We may expect that the profile of IS genetic determinants significantly varies in different ethnic populations.

Serum content of such hormones as IGF1, testosterone, estradiol, leptin, and parathormone as well as matrilin-1 can be used as additional prognostic markers during earlier pubertal period, especially in cases with spine curvature $<30^{\circ}$, which are the most difficult to predict. The melatonin signaling in AIS should be further studied, as this may allow for the development of new diagnostic criteria for predicting curvature onset or progression. The correlation found between the appearance of melatonin signaling impairments in osteoblasts and lymphocytes allows a wider use of this approach for predicting curve onset and progression, especially during earliest stages of the disease [240]. Another intriguing finding is polymorphism of estrogen receptors genes, which suggests defects in estrogen signaling. The role of calmodulin signaling mechanisms in IS requires further clarification. The immune system, including $\mathrm{T}$ and $\mathrm{B}$ cells, may also play a role in pathogenesis of AIS.

The data suggest that progressive, in particular, double spine scoliotic deformity, should be associated with abnormal IVD structure. IVD wedging in AIS begins or enhances at adolescent growth spurt when body weight increases dramatically. The IVD wedging is most prominent in the lumbar spine where axial loading is maximal. Markers of VEPh cell activity at the concave and convex sides suggest that strain at the concave side is probably not enough to reduce cell proliferation during the beginning of curve progression. Thus, earlier wedging of vertebrae may be explained by the prevalence of a laterally directed appositional bone growth at the concave side. If appositional bone growth is also directed anteriorly or posteriorly, it may cause a rotational component of the deformity. This appositional growth results from the interaction of the vertebrae endplate with the outer annulus fibrosus of the adjacent IVD, which is also wedged. This IVD wedging is probably caused by changes in the disc's mechanical properties associated with sparse extracellular matrix and impaired lamellar structure. These are caused by defects in bending proteins, which are synthesized by cells in the IVD and involved in spatial organization of cartilage molecules. A genetic predisposition for increased metalloproteinase activity may also play role in accelerated disc degeneration. Asymmetrical ligament and muscular stretch are also involved in the curve formation and particularly in spine instability [4]. Biomechanical factors modulate the curve formation by gradually forming the "vicious cycle" effect.

We hypothesize that earlier treatment aimed at abnormal intervertebral discs in combination with reasonable spine stabilization may help prevent adjacent vertebrae wedging and curve progression in those patients who are predisposed to severe curve development. The ability to predict curve onset and progression using risk factors assessment could significantly individualize and improve diagnosis and treatment outcomes in patients with IS. The first steps in this field have already been taken, but further research is necessary to develop accurate and sensitive tools for risk assessment.

\section{Conflict of Interests}

The authors declare that there is no conflict of interests regarding the publication of this paper.

\section{References}

[1] I. A. F. Stokes, R. G. Burwell, and P. H. Dangerfield, "Biomechanical spinal growth modulation and progressive adolescent scoliosis-a test of the 'vicious cycle' pathogenetic hypothesis: 
summary of an electronic focus group debate of the IBSE," Scoliosis, vol. 1, no. 1, article 16, 2006.

[2] I. A. F. Stokes, H. Spence, D. D. Aronsson, and N. Kilmer, "Mechanical modulation of vertebral body growth: implications for scoliosis progression," Spine, vol. 21, no. 10, pp. 1162-1167, 1996.

[3] S. Lupparelli, E. Pola, L. Pitta, O. Mazza, V. de Santis, and L. Aulisa, "Biomechanical factors affecting progression of structural scoliotic curves of the spine," Studies in Health Technology and Informatics, vol. 91, pp. 81-85, 2002.

[4] D. Fabris, S. Costantini, U. Nene, V. Lo Scalzo, and F. Finocchiaro, "The surgical treatment of adult lumbar scoliosis," Chirurgia Narzadow Ruchu i Ortopedia Polska, vol. 69, no. 4, pp. 279-285, 2004.

[5] J. F. Fraser, R. C. Huang, F. P. Girardi, and F. P. Cammisa Jr., "Pathogenesis, presentation, and treatment of lumbar spinal stenosis associated with coronal or sagittal spinal deformities," Neurosurgical Focus, vol. 14, no. 1, article e6, 2003.

[6] I. A. F. Stokes and L. Windisch, "Vertebral height growth predominates over intervertebral disc height growth in adolescents with scoliosis," Spine, vol. 31, no. 14, pp. 1600-1604, 2006.

[7] C. T. Mehlman, A. Araghi, and D. R. Roy, "Hyphenated history: the Hueter-Volkmann law," The American Journal of Orthopedics, vol. 26, no. 11, pp. 798-800, 1997.

[8] S. L. Weinstein, The Pediatric Spine: Principles and Practice, Lippincott Williams \& Wilkins, Philadelphia, Pa, USA, 2nd edition, 2001.

[9] I. A. Stokes, J. Gwadera, A. Dimock, C. E. Farnum, and D. D. Aronsson, "Modulation of vertebral and tibial growth by compression loading: diurnal versus full-time loading," Journal of Orthopaedic Research, vol. 23, no. 1, pp. 188-195, 2005.

[10] M. R. Urban, J. C. T. Fairbank, S. R. S. Bibby, and J. P. G. Urban, "Intervertebral disc composition in neuromuscular scoliosis: changes in cell density and glycosaminoglycan concentration at the curve apex," Spine, vol. 26, no. 6, pp. 610-617, 2001.

[11] R. G. Burwell, "Aetiology of idiopathic scoliosis: current concepts," Pediatric Rehabilitation, vol. 6, no. 3-4, pp. 137-170, 2003.

[12] I. A. F. Stokes and D. D. Aronsson, "Disc and vertebral wedging in patients with progressive scoliosis," Journal of Spinal Disorders, vol. 14, no. 4, pp. 317-322, 2001.

[13] P. Fernandes and S. L. Weinstein, "Natural history of early onset scoliosis," Journal of Bone and Joint Surgery A, vol. 89, supplement 1, pp. 21-33, 2007.

[14] B. V. Reamy and J. B. Slakey, "Adolescent idiopathic scoliosis: review and current concepts," The American Family Physician, vol. 64, no. 1, pp. 111-116, 2001.

[15] J. W. Ogilvie, "Adult scoliosis: evaluation and nonsurgical treatment," Instructional Course Lectures, vol. 41, pp. 251-255, 1992.

[16] M. B. Dobbs and S. L. Weinstein, "Infantile and juvenile scoliosis," Orthopedic Clinics of North America, vol. 30, no. 3, pp. 331-341, 1999.

[17] R. Wynne-Davies, "Familial (idiopathic) scoliosis. A family survey," Journal of Bone and Joint Surgery B, vol. 50, no. 1, pp. 24-30, 1968.

[18] O. Diedrich, A. von Strempel, M. Schloz, O. Schmitt, and C. N. Kraft, "Long-term observation and management of resolving infantile idiopathic scoliosis. A 25-year follow-up," Journal of Bone and Joint Surgery B, vol. 84, no. 7, pp. 1030-1035, 2002.

[19] S. L. Weinstein, D. C. Zavala, and I. V. Ponseti, "Idiopathic scoliosis. Long-term follow-up and prognosis in untreated patients," Journal of Bone and Joint Surgery A, vol. 63, no. 5, pp. 702-712, 1981.

[20] R. Wynne Davies, "Infantile idiopathic scoliosis. Causative factors, particularly in the first six months of life," Journal of Bone and Joint Surgery B, vol. 57, no. 2, pp. 138-141, 1975.

[21] P. Gupta, L. G. Lenke, and K. H. Bridwell, "Incidence of neural axis abnormalities in infantile and juvenile patients with spinal deformity: is a magnetic resonance image screening necessary?" Spine, vol. 23, no. 2, pp. 206-210, 1998.

[22] M. B. Dobbs, L. G. Lenke, D. A. Szymanski et al., "Prevelance of neural axis abnormalities in patients with infantile idiopathic scoliosis," Journal of Bone and Joint Surgery A, vol. 84, no. 12, pp. 2230-2234, 2002.

[23] U. M. Figueiredo and J. I. P. James, "Juvenile idiopathic scoliosis," Journal of Bone and Joint Surgery B, vol. 63, no. 1, pp. 61-66, 1981.

[24] V. T. Tolo and R. Gillespie, "The characteristics of juvenile idiopathic scoliosis and results of its treatment," Journal of Bone and Joint Surgery B, vol. 60, no. 2, pp. 181-188, 1978.

[25] Y. P. Charles, J.-P. Daures, V. de Rosa, and A. Diméglio, "Progression risk of idiopathic juvenile scoliosis during pubertal growth," Spine, vol. 31, no. 17, pp. 1933-1942, 2006.

[26] W. J. Kane, "Scoliosis Prevalence: a call for a statement of terms," Clinical Orthopaedics and Related Research, vol. 126, pp. 43-46, 1977.

[27] T. B. Grivas, E. Vasiliadis, V. Mouzakis, C. Mihas, and G. Koufopoulos, "Association between adolescent idiopathic scoliosis prevalence and age at menarche in different geographic latitudes," Scoliosis, vol. 1, no. 1, article 9, 2006.

[28] H.-K. Wong, J. H. P. Hui, U. Rajan, and H.-P. Chia, "Idiopathic scoliosis in Singapore schoolchildren: a prevalence study 15 years into the screening program," Spine, vol. 30, no. 10, pp. 1188-1196, 2005.

[29] S.-W. Suh, H. N. Modi, J.-H. Yang, and J.-Y. Hong, "Idiopathic scoliosis in Korean schoolchildren: a prospective screening study of over 1 million children," European Spine Journal, vol. 20, no. 7, pp. 1087-1094, 2011.

[30] L. Xu, X. Qiu, X. Sun et al., "Potential genetic markers predicting the outcome of brace treatment in patients with adolescent idiopathic scoliosis," European Spine Journal, vol. 20, no. 10, pp. 1757-1764, 2011.

[31] H.-K. Wong and K.-J. Tan, "The natural history of adolescent idiopathic scoliosis," Indian Journal of Orthopaedics, vol. 44, no. 1, pp. 9-13, 2010.

[32] P. N. Soucacos, K. Zacharis, K. Soultanis, J. Gelalis, T. Xenakis, and A. E. Beris, "Risk factors for idiopathic scoliosis: review of a 6-year prospective study," Orthopedics, vol. 23, no. 8, pp. 833$838,2000$.

[33] L.-E. Peterson, A. L. Nachemson, D. S. Bradford et al., "Prediction of progression of the curve in girls who have adolescent idiopathic scoliosis of moderate severity. Logistic regression analysis based on data from the Brace Study of the Scoliosis Research Society," Journal of Bone and Joint Surgery A, vol. 77, no. 6, pp. 823-827, 1995.

[34] J. R. Davids, E. Chamberlin, and D. W. Blackhurst, "Indications for magnetic resonance imaging in presumed adolescent idiopathic scoliosis," Journal of Bone and Joint Surgery A, vol. 86, no. 10, pp. 2187-2195, 2004.

[35] M. O. Andersen, K. Thomsen, and K. O. Kyvik, "Adolescent idiopathic scoliosis in twins: a population-based survey," Spine, vol. 32, no. 8, pp. 927-930, 2007. 
[36] R. G. Burwell, A. A. Cole, T. A. Cook et al., "Pathogenesis of idiopathic scoliosis. The Nottingham concept," Acta Orthopaedica Belgica, vol. 58, supplement 1, pp. 33-58, 1992.

[37] R. G. Burwell, B. J. Freeman, P. H. Dangerfield et al., "Etiologic theories of idiopathic scoliosis: neurodevelopmental concept of maturational delay of the CNS body schema ("body-in-thebrain")," Studies in Health Technology and Informatics, vol. 123, pp. 72-79, 2006.

[38] J. A. Sevastik, "Dysfunction of the autonomic nerve system (ANS) in the aetiopathogenesis of adolescent idiopathic scoliosis," Studies in Health Technology and Informatics, vol. 88, pp. 20-23, 2002.

[39] C. Barrios and J. I. Arrotegui, "Experimental kyphoscoliosis induced in rats by selective brain stem damage," International Orthopaedics, vol. 16, no. 2, pp. 146-151, 1992.

[40] R. Herman, J. Mixon, and A. Fisher, "Idiopathic scoliosis and the central nervous system: a motor control problem. The Harrington Lecture, 1983. Scoliosis Research Society," Spine, vol. 10, no. 1, pp. 1-14, 1985.

[41] X. Sun, Y. Qiu, and Z. Zhu, "Variations of the position of the cerebellar tonsil in adolescent idiopathic scoliosis with severe curves: a MRI study," Studies in Health Technology and Informatics, vol. 123, pp. 565-570, 2006.

[42] Í. T. Benli, O. Üzümcügil, E. Aydin, B. Ateş, L. Gürses, and B. Hekimoğlu, "Magnetic resonance imaging abnormalities of neural axis in Lenke type 1 idiopathic scoliosis," Spine, vol. 31, no. 16, pp. 1828-1833, 2006.

[43] A. E. Oestreich, L. W. Young, and T. Y. Poussaint, "Scoliosis circa 2000: radiologic imaging perspective. I. Diagnosis and pretreatment evaluation," Skeletal Radiology, vol. 27, no. 11, pp. 591-605, 1998.

[44] X. Guo, W. W. Chau, C. W. Y. Hui-Chan, C. S. K. Cheung, W. W. N. Tsang, and J. C. Y. Cheng, "Balance control in adolescents with idiopathic scoliosis and disturbed somatosensory function," Spine, vol. 31, no. 14, pp. E437-E440, 2006.

[45] M. L. M. Lao, D. H. K. Chow, X. Guo, J. C. Y. Cheng, and A. D. Holmes, "Impaired dynamic balance control in adolescents with idiopathic scoliosis and abnormal somatosensory evoked potentials," Journal of Pediatric Orthopaedics, vol. 28, no. 8, pp. 846-849, 2008.

[46] M. Beaulieu, C. Toulotte, L. Gatto et al., "Postural imbalance in non-treated adolescent idiopathic scoliosis at different periods of progression," European Spine Journal, vol. 18, no. 1, pp. 38-44, 2009.

[47] R. G. Burwell, P. H. Dangerfield, B. J. Freeman et al., "Etiologic theories of idiopathic scoliosis: the breaking of bilateral symmetry in relation to left-right asymmetry of internal organs, right thoracic adolescent idiopathic scoliosis (AIS) and vertebrate evolution," Studies in Health Technology and Informatics, vol. 123, pp. 385-390, 2006.

[48] C. J. Goldberg, F. E. Dowling, E. E. Fogarty, and D. P. Moore, "Adolescent idiopathic scoliosis as developmental instability," Genetica, vol. 96, no. 3, pp. 247-255, 1995.

[49] C. J. Goldberg, E. E. Fogarty, D. P. Moore, and F. E. Dowling, "Scoliosis and developmental theory: adolescent idiopathic scoliosis," Spine, vol. 22, no. 19, pp. 2228-2238, 1997.

[50] R. G. Burwell, N. J. James, and F. Johnson, "Standardised trunk asymmetry scores. A study of back contour in healthy schoolchildren," Journal of Bone and Joint Surgery B, vol. 65, no. 4, pp. 452-463, 1983.

[51] A. E. Geissele, M. J. Kransdorf, C. A. Geyer, J. S. Jelinek, and B. E. van Dam, "Magnetic resonance imaging of the brain stem in adolescent idiopathic scoliosis," Spine, vol. 16, no. 7, pp. 761-763, 1991.

[52] M. Nissinen, M. Heliovaara, J. Seitsamo, and M. Poussa, “Trunk asymmetry, posture, growth, and risk of scoliosis: a three-year follow-up of Finnish prepubertal school children," Spine, vol. 18, no. 1 , pp. 8-13, 1993.

[53] H. Normelli, J. A. Sevastik, G. Ljung, and A.-M. Jonsson-Soderstrom, "The symmetry of the breasts in normal and scoliotic girls," Spine, vol. 11, no. 7, pp. 749-752, 1986.

[54] M. Pecina, O. Lulic-Dukic, and A. Pecina-Hrncevic, "Hereditary orthodontic anomalies and idiopathic scoliosis," International Orthopaedics, vol. 15, no. 1, pp. 57-59, 1991.

[55] M. J. Saji, S. S. Upadhyay, and J. C. Y. Leong, "Increased femoral neck-shaft angles in adolescent idiopathic scoliosis," Spine, vol. 20, no. 3, pp. 303-311, 1995.

[56] M. P. Wyatt, R. L. Barrack, and S. J. Mubarak, "Vibratory response in idiopathic scoliosis," Journal of Bone and Joint Surgery B, vol. 68, no. 5, pp. 714-718, 1986.

[57] M. Machida, J. Dubousset, Y. Imamura, T. Iwaya, T. Yamada, and J. Kimura, "An experimental study in chickens for the pathogenesis of idiopathic scoliosis," Spine, vol. 18, no. 12, pp. 1609-1615, 1993.

[58] M. Machida, J. Dubousset, Y. Imamura, Y. Iwaya, T. Yamada, and J. Kimura, "Role of melatonin deficiency in the development of scoliosis in pinealectomised chickens," Journal of Bone and Joint Surgery B, vol. 77, no. 1, pp. 134-138, 1995.

[59] J. Dubousset and M. Machida, "Possible role of pineal gland in pathogenesis of idiopathic scoliosis. Experimental and clinical studies," Bulletin de l'Academie Nationale de Medecine, vol. 185, no. 3, pp. 593-604, 2001.

[60] M. Machida, J. Dubousset, T. Yamada et al., "Experimental scoliosis in melatonin-deficient C57BL/6J mice without pinealectomy," Journal of Pineal Research, vol. 41, no. 1, pp. 17, 2006.

[61] M. Machida, J. Dubousset, Y. Imamura, Y. Miyashita, T. Yamada, and J. Kimura, "Melatonin: a possible role in pathogenesis of adolescent idiopathic scoliosis," Spine, vol. 21, no. 10, pp. 1147$1152,1996$.

[62] K. M. C. Cheung, T. Wang, A. M. S. Poon et al., "The effect of pinealectomy on scoliosis development in young nonhuman primates," Spine, vol. 30, no. 18, pp. 2009-2013, 2005.

[63] K. M. Bagnall, V. J. Raso, D. L. Hill et al., "Melatonin levels in idiopathic scoliosis: diurnal and nocturnal serum melatonin levels in girls with adolescent idiopathic scoliosis," Spine, vol. 21, no. 17, pp. 1974-1978, 1996.

[64] A. S. Hilibrand, L. C. Blakemore, R. T. Loder et al., "The role of melatonin in the pathogenesis of adolescent idiopathic scoliosis," Spine, vol. 21, no. 10, pp. 1140-1146, 1996.

[65] A. B. Fagan, D. J. Kennaway, and A. D. Sutherland, “Total 24hour melatonin secretion in adolescent idiopathic scoliosis: a case-control study," Spine, vol. 23, no. 1, pp. 41-46, 1998.

[66] W. Brodner, P. Krepler, M. Nicolakis et al., "Melatonin and adolescent idiopathic scoliosis," Journal of Bone and Joint Surgery B, vol. 82, no. 3, pp. 399-403, 2000.

[67] K. T. Suh, S. S. Lee, S. J. Kim, Y. K. Kim, and J. S. Lee, "Pineal gland metabolism in patients with adolescent idiopathic scoliosis," Journal of Bone and Joint Surgery B, vol. 89, no. 1, pp. 66-71, 2007.

[68] A. Moreau, D. S. Wang, S. Forget et al., "Melatonin signaling dysfunction in adolescent idiopathic scoliosis," Spine, vol. 29, no. 16, pp. 1772-1781, 2004. 
[69] B. Azeddine, K. Letellier, D. S. Wang, F. Moldovan, and A. Moreau, "Molecular determinants of melatonin signaling dysfunction in adolescent idiopathic scoliosis," Clinical Orthopaedics and Related Research, no. 462, pp. 45-52, 2007.

[70] L. H. S. Sekhon, N. Duggal, J. J. Lynch et al., "Magnetic resonance imaging clarity of the Bryan, Prodisc-C, Prestige LP, and PCM cervical arthroplasty devices," Spine, vol. 32, no. 6, pp. 673-680, 2007.

[71] X. S. Qiu, N. L. S. Tang, H. Y. Yeung et al., "Melatonin receptor $1 \mathrm{~B}$ (MTNR1B) gene polymorphism is associated with the occurrence of adolescent idiopathic scoliosis," Spine, vol. 32, no. 16, pp. 1748-1753, 2007.

[72] J. A. Morcuende, R. Minhas, L. Dolan et al., "Allelic variants of human melatonin $1 \mathrm{~A}$ receptor in patients with familial adolescent idiopathic scoliosis," Spine, vol. 28, no. 17, pp. 20252028, 2003.

[73] M. I. Masana, J. M. Soares Jr., and M. L. Dubocovich, "17 $\beta$ Estradiol modulates hMT1 melatonin receptor function," Neuroendocrinology, vol. 81, no. 2, pp. 87-95, 2005.

[74] K. Letellier, B. Azeddine, S. Parent et al., "Estrogen cross-talk with the melatonin signaling pathway in human osteoblasts derived from adolescent idiopathic scoliosis patients," Journal of Pineal Research, vol. 45, no. 4, pp. 383-393, 2008.

[75] J. Vanecek, "Cellular mechanisms of melatonin action," Physiological Reviews, vol. 78, no. 3, pp. 687-721, 1998.

[76] P. Das, D. J. Schurman, and R. L. Smith, "Nitric oxide and G proteins mediate the response of bovine articular chondrocytes to fluid-induced shear," Journal of Orthopaedic Research, vol. 15, no. 1, pp. 87-93, 1997.

[77] A. J. El Haj, L. M. Walker, M. R. Preston, and S. J. Publicover, "Mechanotransduction pathways in bone: calcium fluxes and the role of voltage-operated calcium channels," Medical and Biological Engineering and Computing, vol. 37, no. 3, pp. 403409, 1999.

[78] G. R. Erickson, L. G. Alexopoulos, and F. Guilak, "Hyperosmotic stress induces volume change and calcium transients in chondrocytes by transmembrane, phospholipid, and G-protein pathways," Journal of Biomechanics, vol. 34, no. 12, pp. 1527-1535, 2001.

[79] F. M. Pavalko, S. M. Norvell, D. B. Burr, C. H. Turner, R. L. Duncan, and J. P. Bidwell, "A model for mechanotransduction in bone cells: the load-bearing mechanosomes," Journal of Cellular Biochemistry, vol. 88, no. 1, pp. 104-112, 2003.

[80] A. Conti, S. Conconi, E. Hertens, K. Skwarlo-Sonta, M. Markowska, and G. J. M. Maestroni, "Evidence for melatonin synthesis in mouse and human bone marrow cells," Journal of Pineal Research, vol. 28, no. 4, pp. 193-202, 2000.

[81] J. A. Roth, B.-G. Kim, F. Song, W.-L. Lin, and M.-I. Cho, "Melatonin promotes osteoblast differentiation and bone formation," Journal of Biological Chemistry, vol. 274, no. 31, pp. 22041-22047, 1999.

[82] H. Koyama, O. Nakade, Y. Takada, T. Kaku, and K.-H. W. Lau, "Melatonin at pharmacologic doses increases bone mass by suppressing resorption through down-regulation of the RANKL-mediated osteoclast formation and activation," Journal of Bone and Mineral Research, vol. 17, no. 7, pp. 1219-1229, 2002.

[83] N. Suzuki and A. Hattori, "Melatonin suppresses osteoclastic and osteoblastic activities in the scales of goldfish," Journal of Pineal Research, vol. 33, no. 4, pp. 253-258, 2002.

[84] D. P. Cardinali, M. G. Ladizesky, V. Boggio, R. A. Cutrera, and C. Mautalen, "Melatonin effects on bone: experimental facts and clinical perspectives," Journal of Pineal Research, vol. 34, no. 2, pp. 81-87, 2003.

[85] M. Ylikoski, "Growth and progression of adolescent idiopathic scoliosis in girls," Journal of Pediatric Orthopaedics Part B, vol. 14, no. 5, pp. 320-324, 2005.

[86] X. Guo, W.-W. Chau, Y.-L. Chan, and J. C.-Y. Cheng, "Relative anterior spinal overgrowth in adolescent idiopathic scoliosis," Journal of Bone and Joint Surgery B, vol. 85, no. 7, pp. 1026-1031, 2003.

[87] X. Guo, W.-W. Chau, Y.-L. Chan, J.-C.-Y. Cheng, R. G. Burwell, and P. H. Dangerfield, "Relative anterior spinal overgrowth in adolescent idiopathic scoliosis-result of disproportionate endochondral-membranous bone growth? Summary of an electronic focus group debate of the IBSE," European Spine Journal, vol. 14, no. 9, pp. 862-873, 2005.

[88] R. W. Porter, “The pathogenesis of idiopathic scoliosis: uncoupled neuro-osseous growth?" European Spine Journal, vol. 10, no. 6, pp. 473-481, 2001.

[89] R. Yarom and G. C. Robin, "Studies on spinal and peripheral muscles from patients with scoliosis," Spine, vol. 4, no. 1, pp. 1221, 1979.

[90] R. Yarom, A. Muhlrad, S. Hodges, and G. C. Robin, "Platelet pathology in patients with idiopathic scoliosis. Ultrastructural morphometry, aggregations, X-ray spectrometry, and biochemical analysis," Laboratory Investigation, vol. 43, no. 3, pp. 208216,1980

[91] T. G. Lowe, M. Edgar, J. Y. Margulies et al., "Etiology of idiopathic scoliosis: current trends in research," Journal of Bone and Joint Surgery A, vol. 82, no. 8, pp. 1157-1168, 2000.

[92] K. Kindsfater, T. Lowe, D. Lawellin, D. Weinstein, and J. Akmakjian, "Levels of platelet calmodulin for the prediction of progression and severity of adolescent idiopathic scoliosis," Journal of Bone and Joint Surgery A, vol. 76, no. 8, pp. 1186-1192, 1994.

[93] T. Lowe, D. Lawellin, D. Smith et al., "Platelet calmodulin levels in adolescent idiopathic scoliosis: do the levels correlate with curve progression and severity?" Spine, vol. 27, no. 7, pp. 768$775,2002$.

[94] T. G. Lowe, R. G. Burwell, and P. H. Dangerfield, "Platelet calmodulin levels in adolescent idiopathic scoliosis (AIS): can they predict curve progression and severity? Summary of an electronic focus group debate of the IBSE," European Spine Journal, vol. 13, no. 3, pp. 257-265, 2004.

[95] R. G. Burwell and P. H. Dangerfield, "Pathogenesis of progressive adolescent idiopathic scoliosis platelet activation and vascular biology in immature vertebrae: an alternative molecular hypothesis," Acta Orthopaedica Belgica, vol. 72, no. 3, pp. 247260, 2006.

[96] M. I. Vacas, M. M. de las del Zar, M. Martinuzzo, and D. P. Cardinali, "Binding sites for $[3 \mathrm{H}]-$-melatonin in human platelets," Journal of Pineal Research, vol. 13, no. 2, pp. 60-65, 1992.

[97] D. P. Cardinali, M. M. del Zar, and M. I. Vacas, "The effects of melatonin in human platelets," Acta Physiologica Pharmacologica et Therapeutica Latinoamericana, vol. 43, no. 1-2, pp. 1-13, 1993.

[98] D. P. Cardinali, D. A. Golombek, R. E. Rosenstein, R. A. Cutrera, and A. I. Esquifino, "Melatonin site and mechanism of action: single or multiple?" Journal of Pineal Research, vol. 23, no. 1, pp. 32-39, 1997. 
[99] J. Yang, J. Wu, M. Anna Kowalska et al., "Loss of signaling through the G protein, $G(z)$, results in abnormal platelet activation and altered responses to psychoactive drugs," Proceedings of the National Academy of Sciences of the United States of America, vol. 97, no. 18, pp. 9984-9989, 2000.

[100] S. I. S. Se Il Suk, I. K. K. In Kwon Kim, C. K. L. Choon Ki Lee, Y. D. K. Young Do Koh, and J. S. Y. Jin Sup Yeom, "A study on platelet function in idiopathic scoliosis," Orthopedics, vol. 14, no. 10, pp. 1079-1083, 1991.

[101] W. K. Ho, M. Baccala, J. Thom, and J. W. Eikelboom, "High prevalence of abnormal preoperative coagulation tests in patients with adolescent idiopathic scoliosis," Journal of Thrombosis and Haemostasis, vol. 3, no. 5, pp. 1094-1095, 2005.

[102] K. Freson, V. Labarque, C. Thys, C. Wittevrongel, and C. V. Geet, "What's new in using platelet research? To unravel thrombopathies and other human disorders," European Journal of Pediatrics, vol. 166, no. 12, pp. 1203-1210, 2007.

[103] A. Pletscher, "Blood platelets as neuronal models: use and limitations," Clinical Neuropharmacology, vol. 9, pp. 344-346, 1986.

[104] N. Hadley-Miller, B. Mims, and D. M. Milewicz, "The potential role of the elastic fiber system in adolescent idiopathic scoliosis," Journal of Bone and Joint Surgery A, vol. 76, no. 8, pp. 1193-1206, 1994.

[105] G. M. Corson, N. L. Charbonneau, D. R. Keene, and L. Y. Sakai, "Differential expression of fibrillin-3 adds to microfibril variety in human and avian, but not rodent, connective tissues," Genomics, vol. 83, no. 3, pp. 461-472, 2004.

[106] E. G. Cleary and M. A. Gibson, "Elastin-associated microfibrils and microfibrillar proteins," International Review of Connective Tissue Research, vol. 10, pp. 97-209, 1983.

[107] M. K. Chelberg, G. M. Banks, D. F. Geiger, and T. R. Oegema Jr., "Identification of heterogeneous cell populations in normal human intervertebral disc," Journal of Anatomy, vol. 186, part 1, pp. 43-53, 1995.

[108] M. Turgut, G. Öktem, A. Uysal, and M. E. Yurtseven, "Immunohistochemical profile of transforming growth factor- $\beta 1$ and basic fibroblast growth factor in sciatic nerve anastomosis following pinealectomy and exogenous melatonin administration in rats," Journal of Clinical Neuroscience, vol. 13, no. 7, pp. 753758, 2006.

[109] L. B. Skogland and J. A. A. Miller, "The length and proportions of the thoracolumbar spine in children with idiopathic scoliosis," Acta Orthopaedica Scandinavica, vol. 52, no. 2, pp. 177-185, 1981.

[110] L. B. Skogland and J. A. A. Miller, "Growth related hormones in idiopathic scoliosis. An endocrine basis for accelerated growth," Acta Orthopaedica Scandinavica, vol. 51, no. 5, pp. 779-789, 1980.

[111] T. Ahl, K. Albertsson-Wikland, and R. Kalen, “Twenty-fourhour growth hormone profiles in pubertal girls with idiopathic scoliosis," Spine, vol. 13, no. 2, pp. 139-142, 1988.

[112] L. B. Skogland, J. A. A. Miller, A. Skottner, and L. Fryklund, "Serum somatomedin A and non-dialyzable urinary hydroxyproline in girls with idiopathic scoliosis," Acta Orthopaedica Scandinavica, vol. 52, no. 3, pp. 307-313, 1981.

[113] E. D. Wang, D. S. Drummond, J. P. Dormans, T. Moshang, R. S. Davidson, and D. Gruccio, "Scoliosis in patients treated with growth hormone," Journal of Pediatric Orthopaedics, vol. 17, no. 6, pp. 708-711, 1997.
[114] J. F. Dymling and S. Willner, "Progression of a structural scoliosis during treatment with growth hormone. A case report," Acta Orthopaedica Scandinavica, vol. 49, no. 3, pp. 264-268, 1978.

[115] G. A. Day, I. B. McPhee, J. Batch, and F. H. Tomlinson, "Growth rates and the prevalence and progression of scoliosis in shortstatured children on Australian growth hormone treatment programmes," Scoliosis, vol. 2, no. 1, article 3, 2007.

[116] C. J. Rosen and L. R. Donahue, "Insulin-like growth factors and bone: the osteoporosis connection revisited," Proceedings of the Society for Experimental Biology and Medicine, vol. 219, no. 1, pp. $1-7,1998$.

[117] X. S. Qiu, N. L. S. Tang, H.-Y. Yeung, Y. Qiu, and J. C. Y. Cheng, "Genetic association study of growth hormone receptor and idiopathic scoliosis," Clinical Orthopaedics and Related Research, vol. 462, pp. 53-58, 2007.

[118] Y. Yang, Z. Wu, T. Zhao et al., "Adolescent idiopathic scoliosis and the single-nucleotide polymorphism of the growth hormone receptor and IGF-1 genes," Orthopedics, vol. 32, no. 6, article 411, 2009.

[119] E. S. Moon, H. S. Kim, V. Sharma et al., "Analysis of single nucleotide polymorphism in adolescent idiopathic scoliosis in Korea: for personalized treatment," Yonsei Medical Journal, vol. 54, no. 2, pp. 500-509, 2013.

[120] J. Falcón, L. Besseau, D. Fazzari et al., "Melatonin modulates secretion of growth hormone and prolactin by trout pituitary glands and cells in culture," Endocrinology, vol. 144, no. 10, pp. 4648-4658, 2003.

[121] Z. Ostrowska, B. Kos-Kudla, E. Swietochowska, B. Marek, D. Kajdaniuk, and N. Ciesielska-Kopacz, "Influence of pinealectomy and long-term melatonin administration on GH-IGF-I axis function in male rats," Neuroendocrinology Letters, vol. 22, no. 4, pp. 255-262, 2001.

[122] P. Lissoni, M. Cazzaniga, G. Tancini et al., "Reversal of clinical resistance to LHRH analogue in metastatic prostate cancer by the pineal hormone melatonin: efficacy of LHRH analogue plus melatonin in patients progressing on LHRH analogue alone," European Urology, vol. 31, no. 2, pp. 178-181, 1997.

[123] J. O. Sanders, R. H. Browne, S. J. McConnell, S. A. Margraf, T. E. Cooney, and D. N. Finegold, "Maturity assessment and curve progression in girls with idiopathic scoliosis," Journal of Bone and Joint Surgery A, vol. 89, no. 1, pp. 64-73, 2007.

[124] J. W. Raczkowski, "The concentrations of testosterone and estradiol in girls with adolescent idiopathic scoliosis," Neuroendocrinology Letters, vol. 28, no. 3, pp. 302-304, 2007.

[125] T. Esposito, R. Uccello, R. Caliendo et al., "Estrogen receptor polymorphism, estrogen content and idiopathic scoliosis in human: a possible genetic linkage," Journal of Steroid Biochemistry and Molecular Biology, vol. 116, no. 1-2, pp. 56-60, 2009.

[126] K. Venken, S. Movérare-Skrtic, J. J. Kopchick et al., "Impact of androgens, growth hormone, and IGF-I on bone and muscle in male mice during puberty," Journal of Bone and Mineral Research, vol. 22, no. 1, pp. 72-82, 2007.

[127] P. Raz, E. Nasatzky, B. D. Boyan, A. Ornoy, and Z. Schwartz, "Sexual dimorphism of growth plate prehypertrophic and hypertrophic chondrocytes in response to testosterone requires metabolism to dihydrotestosterone (DHT) by steroid 5-alpha reductase type 1," Journal of Cellular Biochemistry, vol. 95, no. 1, pp. 108-119, 2005.

[128] R. Luboshitzky, O. Wagner, S. Lavi, P. Herer, and P. Lavie, "Abnormal melatonin secretion in hypogonadal men: the effect of testosterone treatment," Clinical Endocrinology, vol. 47, no. 4, pp. 463-469, 1997. 
[129] A. Kulis, D. Zarzycki, and J. Jaśkiewicz, "Concentration of estradiol in girls with idiophatic scoliosis," Ortopedia Traumatologia Rehabilitacja, vol. 8, no. 4, pp. 455-459, 2006.

[130] A. Kulis and J. Jaśkiewicz, "Concentration of selected regulators of calciumphosphate balance in girls with idiopathic scoliosis," Ortopedia Traumatologia Rehabilitacja, vol. 11, no. 5, pp. 438447, 2009.

[131] C. J. Goldberg, F. E. Dowling, and E. E. Fogarty, "Adolescent idiopathic scoliosis-early menarche, normal growth," Spine, vol. 18 , no. 5, pp. 529-535, 1993.

[132] H. Normelli, J. Sevastik, and G. Ljung, "Anthropometric data relating to normal and scoliotic Scandinavian girls," Spine, vol. 10, no. 2, pp. 123-126, 1985.

[133] W. T. K. Lee, C. S. K. Cheung, Y. K. Tse et al., "Association of osteopenia with curve severity in adolescent idiopathic scoliosis: a study of 919 girls," Osteoporosis International, vol. 16, no. 12, pp. 1924-1932, 2005.

[134] J. C. Cheng, S. P. Tang, X. Guo, C. W. Chan, and L. Qin, "Osteopenia in adolescent idiopathic scoliosis: a histomorphometric study," Spine, vol. 26, no. 3, pp. E19-E23, 2001.

[135] M. N. Weitzmann and R. Pacifici, "Estrogen regulation of immune cell bone interactions," Annals of the New York Academy of Sciences, vol. 1068, no. 1, pp. 256-274, 2006.

[136] A. Bouhoute and G. Leclercq, "Calmodulin decreases the estrogen binding capacity of the estrogen receptor," Biochemical and Biophysical Research Communications, vol. 227, no. 3, pp. 651-657, 1996.

[137] A. S. Dusso and A. J. Brown, "Mechanism of vitamin D action and its regulation," The American Journal of Kidney Diseases, vol. 32, supplement 2, pp. S13-S24, 1998.

[138] H. Chen, S. Shoumura, S. Emura, M. Utsumi, T. Yamahira, and H. Isono, "Effects of melatonin on the ultrastructure of the golden hamster parathyroid gland," Histology and Histopathology, vol. 6, no. 1, pp. 1-7, 1991.

[139] S. Shoumura, H. Chen, S. Emura et al., "An in vitro study on the effects of melatonin on the ultrastructure of the hamster parathyroid gland," Histology and Histopathology, vol. 7, no. 4, pp. 715-718, 1992.

[140] Y. Qiu, X. Sun, X. Qiu et al., "Decreased circulating leptin level and its association with body and bone mass in girls with adolescent idiopathic scoliosis," Spine, vol. 32, no. 24, pp. 27032710, 2007.

[141] X. Sun, Y. Qiu, X.-S. Qiu, Z.-Z. Zhu, F. Zhu, and C.-W. Xia, "Association between circulating leptin level and anthropometric parameters in girls with adolescent idiopathic scoliosis," National Medical Journal of China, vol. 87, no. 9, pp. 594-598, 2007.

[142] J. Xu, T. Wu, Z. Zhong, C. Zhao, Y. Tang, and J. Chen, "Effect and mechanism of leptin on osteoblastic differentiation of hBMSCs," Zhongguo Xiu Fu Chong Jian Wai Ke Za Zhi, vol. 23, no. 2, pp. 140-144, 2009.

[143] S. P. Kalra, M. G. Dube, and U. T. Iwaniec, "Leptin increases osteoblast-specific osteocalcin release through a hypothalamic relay," Peptides, vol. 30, no. 5, pp. 967-973, 2009.

[144] K. Wlodarski and P. Wlodarski, "Leptin as a modulator of osteogenesis," Ortopedia Traumatologia Rehabilitacja, vol. 11, no. 1, pp. 1-6, 2009.

[145] M. I. C. Alonso-Vale, S. Andreotti, S. B. Peres et al., "Melatonin enhances leptin expression by rat adipocytes in the presence of insulin," The American Journal of Physiology-Endocrinology and Metabolism, vol. 288, no. 4, pp. E805-E812, 2005.
[146] R. G. Burwell, R. K. Aujla, M. P. Grevitt et al., "Pathogenesis of adolescent idiopathic scoliosis in girls-a double neuroosseous theory involving disharmony between two nervous systems, somatic and autonomic expressed in the spine and trunk: possible dependency on sympathetic nervous system and hormones with implications for medical therapy," Scoliosis, vol. 4, article 24, 2009.

[147] K. L. Kesling and K. A. Reinker, "Scoliosis in twins: a metaanalysis of the literature and report of six cases," Spine, vol. 22, no. 17, pp. 2009-2015, 1997.

[148] L. M. Kruse, J. G. Buchan, C. A. Gurnett, and M. B. Dobbs, "Polygenic threshold model with sex dimorphism in adolescent idiopathic scoliosis: the Carter effect," Journal of Bone and Joint Surgery, vol. 94, no. 16, pp. 1485-1491, 2012.

[149] C. Brewer, S. Holloway, P. Zawalnyski, A. Schinzel, and D. Fitzpatrick, "A chromosomal deletion map of human malformations," The American Journal of Human Genetics, vol. 63, no. 4, pp. 1153-1159, 1998.

[150] P. F. Giampietro, R. D. Blank, C. L. Raggio et al., "Congenital and idiopathic scoliosis: clinical and genetic aspects," Clinical Medicine \& Research, vol. 1, no. 2, pp. 125-136, 2003.

[151] C. A. Wise, R. Barnes, J. Gillum, J. A. Herring, A. M. Bowcock, and M. Lovett, "Localization of susceptibility to familial idiopathic scoliosis," Spine, vol. 25, no. 18, pp. 2372-2380, 2000.

[152] Y. Takahashi, M. Matsumoto, T. Karasugi et al., "Lack of association between adolescent idiopathic scoliosis and previously reported single nucleotide polymorphisms in MATN1, MTNR1B, TPH1, and IGF1 in a Japanese population," Journal of Orthopaedic Research, vol. 29, no. 7, pp. 1055-1058, 2011.

[153] L. M. Nelson, K. Ward, and J. W. Ogilvie, "Genetic variants in melatonin synthesis and signaling pathway are not associated with adolescent idiopathic scoliosis," Spine, vol. 36, no. 1, pp. 3740, 2011.

[154] X. Gao, D. Gordon, D. Zhang et al., "CHD7 gene polymorphisms are associated with susceptibility to idiopathic scoliosis," The American Journal of Human Genetics, vol. 80, no. 5, pp. 957965, 2007.

[155] L. Montanaro, P. Parisini, T. Greggi et al., "Evidence of a linkage between matrilin-1 gene (MATN1) and idiopathic scoliosis," Scoliosis, vol. 1, no. 1, article 21, 2006.

[156] Z. Chen, N.-L. Tang, X. Cao et al., "Promoter polymorphism of matrilin-1 gene predisposes to adolescent idiopathic scoliosis in a Chinese population," European Journal of Human Genetics, vol. 17, no. 4, pp. 525-532, 2009.

[157] B. Wang, Z.-J. Chen, Y. Qiu, and W.-J. Liu, "Decreased circulating matrilin-1 levels in adolescent idiopathic scoliosis," Zhonghua Wai Ke Za Zhi, vol. 47, no. 21, pp. 1638-1641, 2009.

[158] J. W. Bae, C.-H. Cho, W.-K. Min, and U.-K. Kim, "Associations between matrilin-1 gene polymorphisms and adolescent idiopathic scoliosis curve patterns in a Korean population," Molecular Biology Reports, vol. 39, no. 5, pp. 5561-5567, 2012, Erratum in Molecular Biology Reports, vol. 39, no. 9, p. 9275, 2012.

[159] S. Ohtori, T. Koshi, M. Yamashita et al., "Surgical versus nonsurgical treatment of selected patients with discogenic low back pain: a small-sized randomized trial," Spine, vol. 36, no. 5, pp. 347-354, 2011.

[160] Q. Chen, Y. Zhang, D. M. Johnson, and P. F. Goetinck, "Assembly of a novel cartilage matrix protein filamentous network: molecular basis of differential requirement of von Willebrand factor A domains," Molecular Biology of the Cell, vol. 10, no. 7, pp. 21492162,1999 . 
[161] C. Wiberg, A. R. Klatt, R. Wagener et al., "Complexes of matrilin-1 and biglycan or decorin connect collagen VI microfibrils to both collagen II and aggrecan," Journal of Biological Chemistry, vol. 278, no. 39, pp. 37698-37704, 2003.

[162] I. Kou, Y. Takahashi, T. A. Johnson et al., "Genetic variants in GPR126 are associated with adolescent idiopathic scoliosis," Nature Genetics, vol. 45, no. 6, pp. 676-679, 2013.

[163] Weizman Institute of Science, "Gene Card. The human gene compendium," 2013, http://www.genecards.org/cgi-bin/ carddisp.pl?gene $=\mathrm{LBX} 1 \&$ search $=\mathrm{LBX} 1$.

[164] C. M. Justice, N. H. Miller, B. Marosy, J. Zhang, and A. F. Wilson, "Familial idiopathic scoliosis: evidence of an X-linked susceptibility locus," Spine, vol. 28, no. 6, pp. 589-594, 2003.

[165] V. Chan, G. C. Y. Fong, K. D. K. Luk et al., "A genetic locus for adolescent idiopathic scoliosis linked to chromosome 19p13.3," The American Journal of Human Genetics, vol. 71, no. 2, pp. 401406, 2002.

[166] X.-B. Cao, Y. Qiu, and X.-S. Qiu, "FBN3 gene polymorphisms in adolescent idiopathic scoliosis patients," Zhonghua Yi Xue Za Zhi, vol. 88, no. 43, pp. 3053-3058, 2008.

[167] M. Inoue, S. Minami, Y. Nakata et al., "Association between estrogen receptor gene polymorphisms and curve severity of idiopathic scoliosis," Spine, vol. 27, no. 21, pp. 2357-2362, 2002.

[168] J. Wu, Y. Qiu, L. Zhang, Q. Sun, X. Qiu, and Y. He, "Association of estrogen receptor gene polymorphisms with susceptibility to adolescent idiopathic scoliosis," Spine, vol. 31, no. 10, pp. 11311136, 2006.

[169] N. L.-S. Tang, H.-Y. Yeung, K.-M. Lee et al., "A relook into the association of the estrogen receptor $\alpha$ gene (PvuII, XbaI) and adolescent idiopathic scoliosis: a study of 540 Chinese cases," Spine, vol. 31, no. 21, pp. 2463-2468, 2006.

[170] D. Zhao, G.-X. Qiu, and Y.-P. Wang, "Is calmodulin 1 gene/estrogen receptor-alpha gene polymorphisms correlated with double curve pattern of adolescent idiopathic scoliosis?" Zhonghua Yi Xue Za Zhi, vol. 88, no. 35, pp. 2452-2456, 2008.

[171] D. Zhao, G.-X. Qiu, Y.-P. Wang et al., "Association of calmodulinl gene polymorphisms with susceptibility to adolescent idiopathic scoliosis," Orthopaedic Surgery, vol. 1, no. 1, pp. 5865, 2009.

[172] H.-Q. Zhang, S.-J. Lu, M.-X. Tang et al., "Association of estrogen receptor $\beta$ gene polymorphisms with susceptibility to adolescent idiopathic scoliosis," Spine, vol. 34, no. 8, pp. 760764, 2009.

[173] Y. Takahashi, M. Matsumoto, T. Karasugi et al., "Replication study of the association between adolescent idiopathic scoliosis and two estrogen receptor genes," Journal of Orthopaedic Research, vol. 29, no. 6, pp. 834-837, 2011.

[174] Y. Peng, G. Liang, Y. Pei, W. Ye, A. Liang, and P. Su, "Genomic polymorphisms of G-Protein Estrogen Receptor 1 are associated with severity of adolescent idiopathic scoliosis," International Orthopaedics, vol. 36, no. 3, pp. 671-677, 2012.

[175] Y. Qiu, S.-H. Mao, B.-P. Qian et al., "A promoter polymorphism of neurotrophin 3 gene is associated with curve severity and bracing effectiveness in adolescent idiopathic scoliosis," Spine, vol. 37, no. 2, pp. 127-133, 2012.

[176] Y. Ogura, Y. Takahashi, I. Kou et al., "A replication study for association of 5 single nucleotide polymorphisms with curve progression of adolescent idiopathic scoliosis in Japanese patients," Spine, vol. 38, no. 7, pp. 571-575, 2013.

[177] A. M. Zaidman, M. N. Zaidman, A. V. Korel, M. A. Mikhailovsky, T. Y. Eshchenko, and E. V. Grigorjeva, "Aggrecan gene expression disorder as aetiologic factor of idiopathic scoliosis," Studies in Health Technology and Informatics, vol. 123, pp. 14-17, 2006.

[178] B. Marosy, C. M. Justice, N. Nzegwu, G. Kumar, A. F. Wilson, and N. H. Miller, "Lack of association between the aggrecan gene and familial idiopathic scoliosis," Spine, vol. 31, no. 13, pp. 1420-1425, 2006.

[179] N. H. Miller, B. Mims, A. Child, D. M. Milewicz, P. Sponseller, and S. H. Blanton, "Genetic analysis of structural elastic fiber and collagen genes in familial adolescent idiopathic scoliosis," Journal of Orthopaedic Research, vol. 14, no. 6, pp. 994-999, 1996.

[180] B. Marosy, C. M. Justice, C. Vu et al., "Identification of susceptibility loci for scoliosis in FIS families with triple curves," The American Journal of Medical Genetics A, vol. 152, no. 4, pp. 846-855, 2010.

[181] L. Baghernajad Salehi, M. Mangino, S. de Serio et al., "Assignment of a locus for autosomal dominant idiopathic scoliosis (IS) to ohuman chromosome 17p11," Human Genetics, vol. 111, no. 45, pp. 401-404, 2002.

[182] I.-S. Eun, W. W. Park, K. T. Suh, J. I. Kim, and J. S. Lee, "Association between osteoprotegerin gene polymorphism and bone mineral density in patients with adolescent idiopathic scoliosis," European Spine Journal, vol. 18, no. 12, pp. 1936-1940, 2009.

[183] H. Wang, Z. Wu, Q. Zhuang et al., "Association study of tryptophan hydroxylase 1 and arylalkylamine n-acetyltransferase polymorphisms with adolescent idiopathic scoliosis in han chinese," Spine, vol. 33, no. 20, pp. 2199-2203, 2008.

[184] L. Aulisa, P. Papaleo, E. Pola et al., "Association between IL6 and MMP-3 gene polymorphisms and adolescent idiopathic scoliosis: a case-control study," Spine, vol. 32 , no. 24 , pp. $2700-$ 2702, 2007.

[185] Z. Liu, N. L. S. Tang, X.-B. Cao et al., "Lack of association between the promoter polymorphisms of MMP-3 and IL-6 genes and adolescent idiopathic scoliosis: a case-control study in a chinese han population," Spine, vol. 35, no. 18, pp. 1701-1705, 2010.

[186] J. S. Lee, K. T. Suh, and I. S. Eun, "Polymorphism in interleukin6 gene is associated with bone mineral density in patients with adolescent idiopathic scoliosis," Journal of Bone and Joint Surgery B, vol. 92, no. 8, pp. 1118-1122, 2010.

[187] S. Zhou, X. S. Qiu, Z. Z. Zhu, W. F. Wu, Z. Liu, and Y. Qiu, "A single-nucleotide polymorphism rs708567 in the IL-17RC gene is associated with a susceptibility to and the curve severity of adolescent idiopathic scoliosis in a Chinese Han population: a case-control study," Musculoskeletal Disorders, vol. 13, article 181, 2012.

[188] M. Mórocz, Á. Czibula, Z. B. Grózer et al., "Association study of BMP4, IL6, Leptin, MMP3, and MTNR1B gene promoter polymorphisms and adolescent idiopathic scoliosis," Spine, vol. 36, no. 2, pp. E123-E130, 2011.

[189] K. T. Suh, I.-S. Eun, and J. S. Lee, "Polymorphism in vitamin D receptor is associated with bone mineral density in patients with adolescent idiopathic scoliosis," European Spine Journal, vol. 19, no. 9, pp. 1545-1550, 2010.

[190] C.-W. Xia, Y. Qiu, X. Sun et al., "Vitamin D receptor gene polymorphisms in female adolescent idiopathic scoliosis patients," National Medical Journal of China, vol. 87, no. 21, pp. 1465-1469, 2007.

[191] W.-J. Chen, Y. Qiu, F. Zhu et al., "Vitamin D receptor gene polymorphisms: no association with low bone mineral density 
in adolescent idiopathic scoliosis girls," Zhonghua Wai Ke Za Zhi, vol. 46, no. 15, pp. 1183-1186, 2008.

[192] Y. Takahashi, I. Kou, A. Takahashi et al., "A genome-wide association study identifies common variants near LBX1 associated with adolescent idiopathic scoliosis," Nature Genetics, vol. 43, no. 12, pp. 1237-1240, 2011.

[193] W. Gao, Y. Peng, G. Liang et al., "Association between common variants near LBX1 and adolescent idiopathic scoliosis replicated in the Chinese Han population," PLOS ONE, vol. 8, no. 1, Article ID e53234, 2013.

[194] Y.-H. Fan, Y.-Q. Song, D. Chan et al., “SNP rs11190870 near LBX1 is associated with adolescent idiopathic scoliosis in southern Chinese," Journal of Human Genetics, vol. 57, no. 4, pp. 244-246, 2012.

[195] S. Sharma, X. Gao, D. Londono et al., "Genome-wide association studies of adolescent idiopathic scoliosis suggest candidate susceptibility genes," Human Molecular Genetics, vol. 20, no. 7, pp. 1456-1466, 2011.

[196] S. Mao, L. Xu, Z. Zhu et al., "Association between genetic determinants of peak height velocity during puberty and predisposition to adolescent idiopathic scoliosis," Spine, vol. 38, no. 12, pp. 1034-1039, 2013.

[197] T. Yang, Q. Jia, H. Guo et al., "Epidemiological survey of idiopathic scoliosis and sequence alignment analysis of multiple candidate genes," International Orthopaedics, vol. 36, no. 6, pp. 1307-1314, 2012.

[198] D.-S. Huang, G.-Y. Liang, and P.-Q. Su, "Association of matrix metalloproteinase 9 polymorphisms with adolescent idiopathic scoliosis in Chinese Han female," Chinese Journal of Medical Genetics, vol. 28, no. 5, pp. 532-535, 2011.

[199] H. Wang, Z.-H. Wu, Q.-Y. Zhuang, and G.-X. Qiu, "Association study of HTR1A and HTR1B with adolescent idiopathic scoliosis," Zhonghua Wai Ke Za Zhi, vol. 48, no. 4, pp. 296-299, 2010.

[200] J. Jiang, Y. Qiu, B.-P. Qian et al., "Association between tissue inhibitor of metalloproteinase-2 gene polymorphism and adolescent idiopathic thoracic scoliosis," Zhonghua Wai Ke Za Zhi, vol. 48, no. 6, pp. 423-426, 2010.

[201] Q.-Y. Zhuang, Z.-H. Wu, and G.-X. Qiu, "Is polymorphism of CALM1 gene or growth hormone receptor gene associated with susceptibility to adolescent idiopathic scoliosis?" Chinese Medical Journal, vol. 87, no. 31, pp. 2198-2202, 2007.

[202] Axial Biotech, "ScoliScore AIS Prognostic Test," Axial Biotech Inc., Salt Lake City, Utah, USA, 2010, http://www.axialbiotech .com/.

[203] K. Ward, J. W. Ogilvie, M. V. Singleton, R. Chettier, G. Engler, and L. M. Nelson, "Validation of DNA-based prognostic testing to predict spinal curve progression in adolescent idiopathic scoliosis," Spine, vol. 35, no. 25, pp. E1455-E1464, 2010.

[204] T. B. Grivas, E. Vasiliadis, M. Malakasis, V. Mouzakis, and D. Segos, "Intervertebral disc biomechanics in the pathogenesis of idiopathic scoliosis," Studies in Health Technology and Informatics, vol. 123, pp. 80-83, 2006.

[205] H. N. Modi, S. W. Suh, H.-R. Song, J.-H. Yang, H.-J. Kim, and C. H. Modi, "Differential wedging of vertebral body and intervertebral disc in thoracic and lumbar spine in adolescent idiopathic scoliosis-a cross sectional study in 150 patients," Scoliosis, vol. 3, no. 1, article 11, 2008.

[206] S. Nomura and T. Takano-Yamamoto, "Molecular events caused by mechanical stress in bone," Matrix Biology, vol. 19, no. 2, pp. 91-96, 2000.
[207] A. Liedert, D. Kaspar, R. Blakytny, L. Claes, and A. Ignatius, "Signal transduction pathways involved in mechanotransduction in bone cells," Biochemical and Biophysical Research Communications, vol. 349, no. 1, pp. 1-5, 2006.

[208] D. J. Papachristou, K. K. Papachroni, E. K. Basdra, and A. G. Papavassiliou, "Signaling networks and transcription factors regulating mechanotransduction in bone," BioEssays, vol. 31, no. 7, pp. 794-804, 2009.

[209] K.-H. W. Lau, S. Kapur, C. Kesavan, and D. J. Baylink, "Upregulation of the Wnt, estrogen receptor, insulin-like growth factor-I, and bone morphogenetic protein pathways in C57BL/6J osteoblasts as opposed to $\mathrm{C} 3 \mathrm{H} / \mathrm{HeJ}$ osteoblasts in part contributes to the differential anabolic response to fluid shear," Journal of Biological Chemistry, vol. 281, no. 14, pp. 9576-9588, 2006.

[210] H. M. Frost, "A 2003 update of bone physiology and Wolff s law for clinicians," Angle Orthodontist, vol. 74, no. 1, pp. 3-15, 2004.

[211] J. Sarwark and C.-É. Aubin, "Growth considerations of the immature spine," Journal of Bone and Joint Surgery A, vol. 89, supplement 1, pp. 8-13, 2007.

[212] A. Meir, D. S. McNally, J. C. Fairbank, D. Jones, and J. P. Urban, "The internal pressure and stress environment of the scoliotic intervertebral disc-a review," Proceedings of the Institution of Mechanical Engineers H, vol. 222, no. 2, pp. 209-219, 2008.

[213] A. R. Meir, J. C. T. Fairbank, D. A. Jones, D. S. McNally, and J. P. G. Urban, "High pressures and asymmetrical stresses in the scoliotic disc in the absence of muscle loading," Scoliosis, vol. 2, no. 1, article 4, 2007.

[214] W. E. B. Johnson and S. Roberts, "Human intervertebral disc cell morphology and cytoskeletal composition: a preliminary study of regional variations in health and disease," Journal of Anatomy, vol. 203, no. 6, pp. 605-612, 2003.

[215] J. L. Ford, P. Jones, and S. Downes, "Cellularity of human annulus tissue: an investigation into the cellularity of tissue of different pathologies," Histopathology, vol. 41, no. 6, pp. 531-537, 2002.

[216] H. Bertram, E. Steck, G. Zimmermann et al., "Accelerated intervertebral disc degeneration in scoliosis versus physiological ageing develops against a background of enhanced anabolic gene expression," Biochemical and Biophysical Research Communications, vol. 342, no. 3, pp. 963-972, 2006.

[217] J. Antoniou, V. Arlet, T. Goswami, M. Aebi, and M. Alini, "Elevated synthetic activity in the convex side of scoliotic intervertebral discs and endplates compared with normal tissues," Spine, vol. 26, no. 10, pp. E198-206, 2001.

[218] S. Stern, K. Lindenhayn, and C. Perka, "Human intervertebral disc cell culture for disc disorders," Clinical Orthopaedics and Related Research, no. 419, pp. 238-244, 2004.

[219] J. Yu, J. C. T. Fairbank, S. Roberts, and J. P. G. Urban, "The elastic fiber network of the anulus fibrosus of the normal and scoliotic human intervertebral disc," Spine, vol. 30, no. 16, pp. 1815-1820, 2005.

[220] S. Akhtar, J. R. Davies, and B. Caterson, "Ultrastructural immunolocalization of $\alpha$-elastin and keratan sulfate proteoglycan in normal and scoliotic lumbar disc," Spine, vol. 30, no. 15, pp. 1762-1769, 2005.

[221] S. Roberts, J. Menage, and S. M. Eisenstein, "The cartilage endplate and intervertebral disc in scoliosis: calcification and other sequelae," Journal of Orthopaedic Research, vol. 11, no. 5, pp. 747757, 1993. 
[222] L. Haglund, J. Ouellet, and P. Roughley, "Variation in chondroadherin abundance and fragmentation in the human scoliotic disc," Spine, vol. 34, no. 14, pp. 1513-1518, 2009.

[223] A. Pedrini Mille, V. A. Pedrini, and C. Tudisco, "Proteoglycans of human scoliotic intervertebral disc," Journal of Bone and Joint Surgery A, vol. 65, no. 6, pp. 815-823, 1983.

[224] Y. He, Y. Qiu, F. Zhu, and Z. Zhu, "Quantitative analysis of types I and II collagen in the disc annulus in adolescent idiopathic scoliosis," Studies in Health Technology and Informatics, vol. 123, pp. 123-128, 2006.

[225] Q. Lin, Z.-H. Wu, Y. Liu et al., "Gene expression of type $\mathrm{X}$ collagen in the intervertebral disc of idiopathic scoliosis patients," Zhongguo Yi Xue Ke Xue Yuan Xue Bao, vol. 26, no. 6, pp. 696-699, 2004.

[226] S. Roberts, E. H. Evans, D. Kletsas, D. C. Jaffray, and S. M. Eisenstein, "Senescence in human intervertebral discs," European Spine Journal, vol. 15, supplement 3, pp. S312-S316, 2006.

[227] B. Chen, J. Fellenberg, H. Wang, C. Carstens, and W. Richter, "Occurrence and regional distribution of apoptosis in scoliotic discs," Spine, vol. 30, no. 5, pp. 519-524, 2005.

[228] J. K. G. Crean, S. Roberts, D. C. Jaffray, S. M. Eisenstein, and V. C. Duance, "Matrix metalloproteinases in the human intervertebral disc: role in disc degeneration and scoliosis," Spine, vol. 22, no. 24, pp. 2877-2884, 1997.

[229] G. R. Buttermann and W. J. Mullin, "Pain and disability correlated with disc degeneration via magnetic resonance imaging in scoliosis patients," European Spine Journal, vol. 17, no. 2, pp. 240-249, 2008.

[230] Y. Qiu and F. Zhu, "Anterior and posterior spinal growth plates in adolescent idiopathic scoliosis: a histological study," Zhongguo Yi Xue Ke Xue Yuan Xue Bao, vol. 27, no. 2, pp. 148152, 2005.

[231] F. Zhu, Y. Qiu, H. Y. Yeung, K. M. Lee, and J. C.-Y. Cheng, "Histomorphometric study of the spinal growth plates in idiopathic scoliosis and congenital scoliosis," Pediatrics International, vol. 48, no. 6, pp. 591-598, 2006.

[232] S. Wang, Y. Qiu, Z. Zhu, Z. Ma, C. Xia, and F. Zhu, "Histomorphological study of the spinal growth plates from the convex side and the concave side in adolescent idiopathic scoliosis," Journal of Orthopaedic Surgery and Research, vol. 2, no. 1, article 19, 2007.

[233] H. Xu, G. Qiu, Z. Wu et al., "Expression of transforming growth factor and basic fibroblast growth factor and core protein of proteoglycan in human vertebral cartilaginous endplate of adolescent idiopathic scoliosis," Spine, vol. 30, no. 17, pp. 19731978, 2005.

[234] G.-X. Qiu, Q.-Y. Li, Y. Liu et al., "Expression of transforming growth factor- $\beta 1$ and basic fibroblast growth factor in articular process cartilages of adolescent idiopathic scoliosis," National Medical Journal of China, vol. 86, no. 21, pp. 1478-1483, 2006.

[235] Y. Chen, Y. Hu, and Z. Lü, "Regulating effects of transforming growth factor-beta (TGF-beta) on gene expression of collagen type II in human intervertebral discs," Zhonghua Wai Ke Za Zhi, vol. 38, no. 9, pp. 703-706, 2000.

[236] M. Turgut, G. Öktem, S. Uslu, M. E. Yurtseven, H. Aktuğ, and A. Uysal, "The effect of exogenous melatonin administration on trabecular width, ligament thickness and TGF- $\beta 1$ expression in degenerated intervertebral disk tissue in the rat," Journal of Clinical Neuroscience, vol. 13, no. 3, pp. 357-363, 2006.

[237] E. Solheim, "Growth factors in bone," International Orthopaedics, vol. 22, no. 6, pp. 410-416, 1998.
[238] H.-J. Im, P. Muddasani, V. Natarajan et al., "Basic fibroblast growth factor stimulates matrix metalloproteinase- 13 via the molecular cross-talk between the mitogen-activated protein kinases and protein kinase $\mathrm{C} \delta$ pathways in human adult articular chondrocytes," Journal of Biological Chemistry, vol. 282, no. 15, pp. 11110-11121, 2007.

[239] E. Scott Graham, D. G. Hazlerigg, and P. J. Morgan, "Evidence for regulation of basic fibroblast growth factor gene expression by photoperiod and melatonin in the ovine pars tuberalis," Molecular and Cellular Endocrinology, vol. 156, no. 1-2, pp. 4553, 1999.

[240] M.-Y. Akoume, B. Azeddine, I. Turgeon et al., "Cell-based screening test for idiopathic scoliosis using cellular dielectric spectroscopy," Spine, vol. 35, no. 13, pp. E601-E608, 2010. 


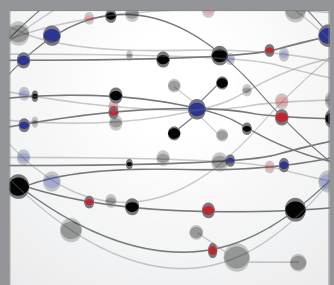

The Scientific World Journal
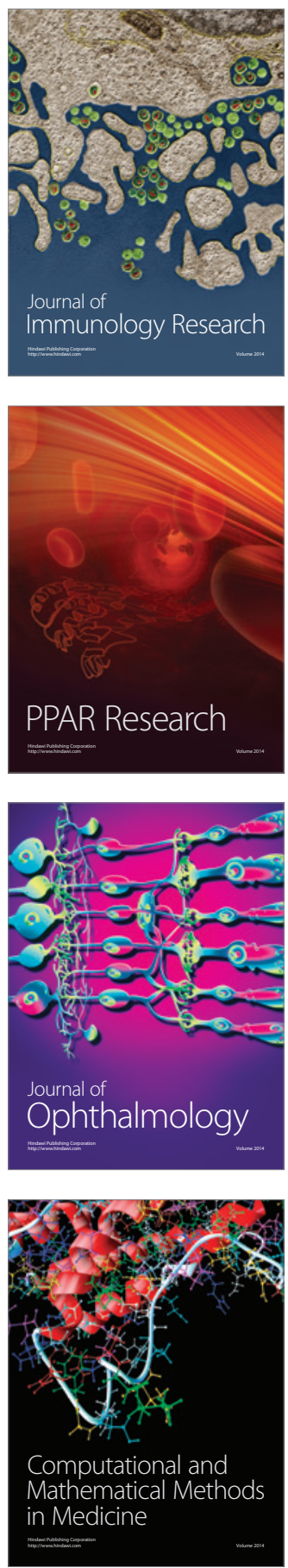

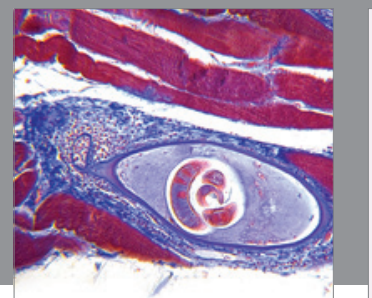

Gastroenterology

Research and Practice
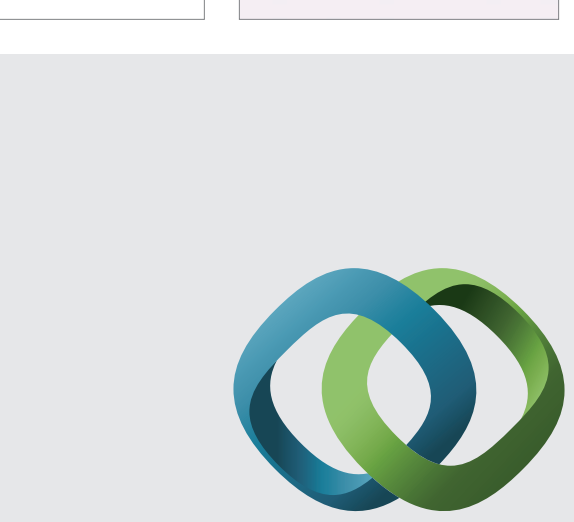

\section{Hindawi}

Submit your manuscripts at

http://www.hindawi.com
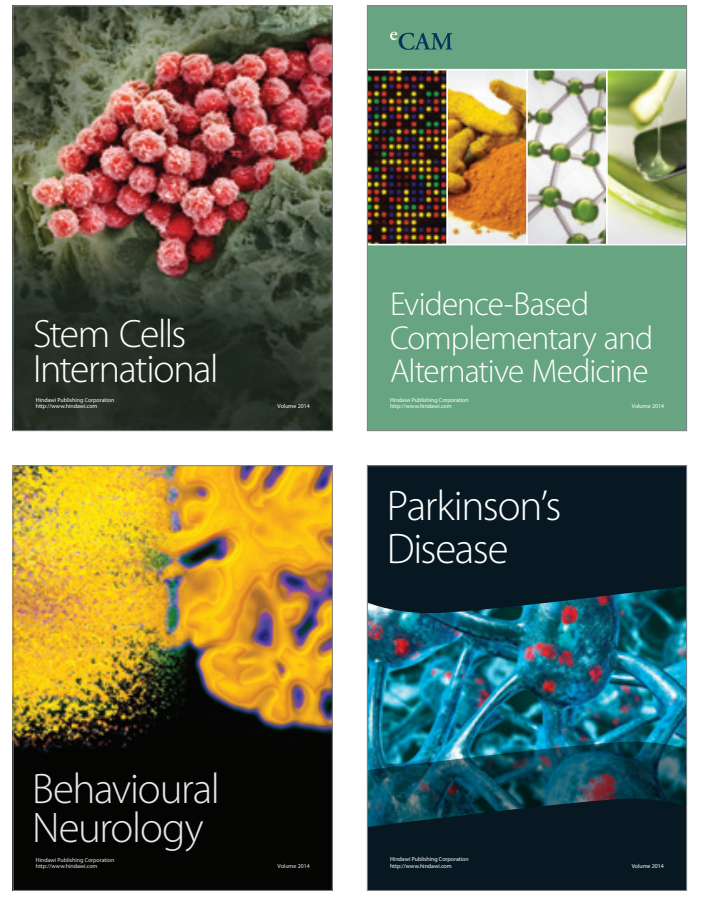
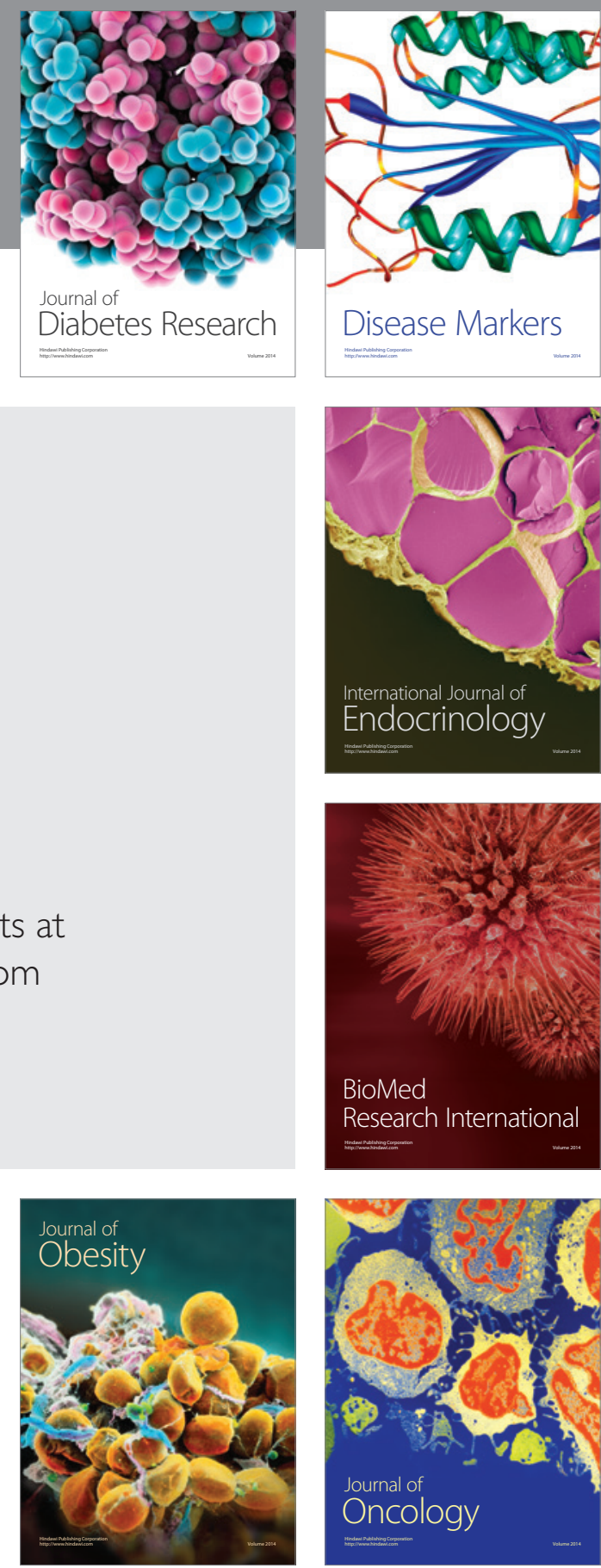

Disease Markers
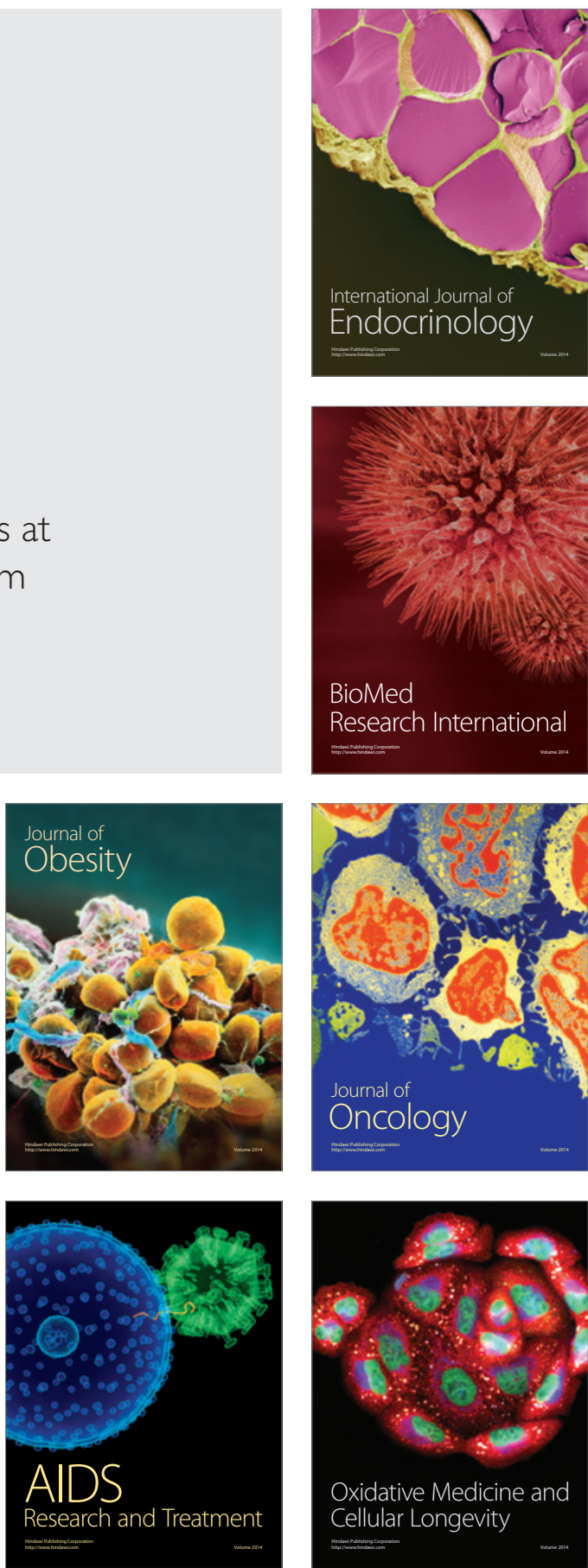